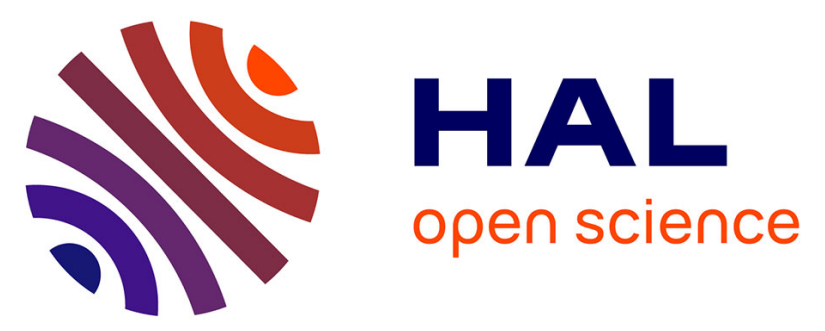

\title{
Integrated 3D geological modelling of the northern Upper Rhine Graben by joint inversion of gravimetry and magnetic data
}

\author{
Matthis Frey, Sebastian Weinert, Kristian Bär, Jeroen van Der Vaart, \\ Chrystel Dezayes, Philippe Calcagno, Ingo Sass
}

\section{To cite this version:}

Matthis Frey, Sebastian Weinert, Kristian Bär, Jeroen van Der Vaart, Chrystel Dezayes, et al.. Integrated 3D geological modelling of the northern Upper Rhine Graben by joint inversion of gravimetry and magnetic data. Tectonophysics, 2021, 813, pp.228927. 10.1016/j.tecto.2021.228927 . hal03234500

\section{HAL Id: hal-03234500 https: / hal-brgm.archives-ouvertes.fr/hal-03234500}

Submitted on 22 Jul 2021

HAL is a multi-disciplinary open access archive for the deposit and dissemination of scientific research documents, whether they are published or not. The documents may come from teaching and research institutions in France or abroad, or from public or private research centers.
L'archive ouverte pluridisciplinaire HAL, est destinée au dépôt et à la diffusion de documents scientifiques de niveau recherche, publiés ou non, émanant des établissements d'enseignement et de recherche français ou étrangers, des laboratoires publics ou privés. 
Manuscript: "Integrated 3D Geological Modelling of the Northern Upper Rhine Graben by Joint Inversion of Gravimetry and Magnetic Data"

Authors: $\quad$ Matthis Frey ${ }^{[a]}$, Sebastian Weinert ${ }^{[a, b]}$, Kristian Bär ${ }^{[a]}$, Jeroen van der Vaart ${ }^{[a]}$, Chrystel Dezayes ${ }^{[c]}$, Philippe Calcagno ${ }^{[c]}$, Ingo Sass ${ }^{[a, b]}$, a ... Technical University of Darmstadt, Institute of Applied Geosciences, Department of Geothermal Science and Technology, Schnittspahnstraße 9, 64287 Darmstadt, Germany b ... Darmstadt Graduate School of Excellence Energy Science and Engineering, Otto-Berndt-Straße 3, 64287 Darmstadt, Germany c ... BRGM, 3, avenue Claude Guillemin, BP36009, 45060 Orléans cedex, France

Corresponding Author: Matthis Frey frey@geo.tu-darmstadt.de

Office: +49 61511622299

Mobile: +4915227522447

Schnittspahnstraße 9, 64287 Darmstadt, Germany 


\section{CRediT author statement:}

21 Matthis Frey: Conceptualization, Investigation, Methodology, Validation, Writing - Original

22 Draft, Visualization

23 Sebastian Weinert: Methodology, Investigation, Writing - Review \& Editing

24 Kristian Bär: Conceptualization, Writing - Review \& Editing, Supervision, Project

25 administration, Funding acquisition

26 Jeroen van der Vaart: Methodology, Writing - Review \& Editing, Project administration

27 Chrystel Dezayes: Resources, Writing - Review \& Editing

28 Phillipe Calcagno: Resources, Writing - Review \& Editing

29 Ingo Sass: Writing - Review \& Editing, Supervision, Project administration 


\section{Abstract}

31 The crystalline basement of the Upper Rhine Graben is a major target for deep geothermal

32 exploration due to the generally high reservoir temperatures and the increased radiogenic heat 33 production. The geothermal potential is strongly dependent on the lithology, because mainly 34 the thermal but also the hydraulic properties are affected the rock type. For this reason, the so far most detailed 3D model of the basement in the northern Upper Rhine Graben was developed, based on existing structural models, in particular the Hesse 3D 2.0 and GeORG models. Since only a few boreholes fully penetrate the thick sediment cover, additional magnetic and gravity data provided valuable information on the geometry of the deep horizons. To interpret the Bouguer anomalies reasonably with respect to the crystalline basement, the regional gravity field and sedimentary effect were subtracted from the observed data. In comparison to the commonly applied deterministic modelling approaches, a stochastic joint inversion of the gravity and magnetic anomalies was performed that utilizes the principles of a Monte-Carlo-Markov-Chain simulation. For an appropriate attribution of the model units, existing petrophysical databases of the region have been used and in addition, the magnetic susceptibility of more than 430 rock samples was measured. High-resolution voxel models of the density and susceptibility distribution were generated as a result of the inversion, which allow conclusions about the crustal composition under the sedimentary formations. An interpretative map of the basement geology, derived from the inversion results, is presented.

51 Keywords: Upper Rhine Graben, Joint Inversion, Gravity, Magnetics, 3D modelling, 


\section{Introduction}

The Upper Rhine Graben (URG), with its elevated geothermal gradient of locally more than $100{ }^{\circ} \mathrm{C} / \mathrm{km}$ (Agemar et al., 2012), is one of the main targets for geothermal research and exploitation in Central Europe. Besides the sedimentary horizons, the crystalline basement is due to the favorable temperatures attractive for deep geothermal projects in this region (e.g. Jain et al., 2015). Currently, the power plants in Landau, Insheim, Rittershoffen and Soultzsous-Forêts, use inter alia the top basement for heat or heat and power co generation. On top of that, several other projects throughout the entire URG are in planning or under development.

The deep geothermal potential of crystalline reservoirs depends on a number of parameters, which are primarily controlled by the respective lithology. First, the thermal structure of the crust in the URG is, in addition to the shallow Moho depth and the deep fluid circulation patterns along large-scale fault zones (Bächler et al., 2003), directly related to the radiogenic heat production of the basement (Jaupart et al., 2016; Lachenbruch, 1970; Mareschal and Jaupart, 2013). While the highest values are measured in granites due to the increased concentration of radioactive elements, the heat production of mafic rocks is on average almost one magnitude smaller (Vilà et al., 2010). Likewise, the thermal conductivity of granites is by a factor of 1.3 higher than in gabbros (Weinert et al., 2020a). In addition, also the hydraulic conductivity of the basement is strongly influenced by the lithology. Stober and Bucher (2007) could show from hydraulic test data in the Black Forest that granites have on average 2 magnitudes higher natural permeabilities than gneiss. This observation can be attributed, on the one hand, to the significant permeability anisotropy due to layered mica minerals in gneisses and, on the other hand, to the preferred fracturing along those layers with an increased tendency of reclosing. In summary, felsic intrusions represent the preferred targets for deep geothermal wells, whereas mafic and metamorphic rocks have less advantageous thermal and hydraulic properties.

In the URG, knowledge about the basement structure and composition beneath the sedimentary cover is limited due to the scarcity of very deep wells reaching crystalline rocks and crustal-scale seismic profiles such as the DEKORP 9N line. (Brun et al., 1992; Meier and Eisbacher, 1991; Meissner and Bortfeld, 1990). Key information is therefore mainly provided by the crystalline outcrops at the graben borders, which for example allow the conduction of analogue studies (Bär, 2012; Dezayes et al., 2021; Weinert et al., 2020a; Welsch et al., 2014). Additional constraints are given by gravity and magnetic data that are available throughout the whole area. In the past decades, several attempts have already been made to model the crystalline basement based on the available data and to determine its properties more precisely. In this context, the work of Edel and Fluck (1989), Rousset et al. (1993), Rotstein et al. (2006), Edel and Schulmann (2009), Baillieux et al. (2013), Freymark et al. (2015), 
Freymark et al. (2017), Edel et al. (2018) and Weinert et al. (2021, in prep.) should be mentioned. In contrast to these studies, a joint inversion of gravity and magnetic data was performed, that has already been successfully applied in other regions (Frey and Ebbing, 2020; Gallardo and Thebaud, 2012; Kamm et al., 2015). Compared to time-consuming forward modelling, this approach automatically generates complex petrophysical models that are moreover easily reproducible. From these, the basement lithology can be deduced, which will enable more reliable estimates of geothermal potentials in the future.

Inversions are widely used in the geosciences to infer the distribution of petrophysical properties in the subsurface from physical parameters measured at the surface, such as the arrival times of seismic waves, the acceleration of gravity or the magnetic field strength (Bosch and McGaughey, 2001; Li and Oldenburg, 1996, 1998). From this, information about geological structures can be derived. With advancing computer capacity, calculation-intensive stochastic inversions, like the Monte-Carlo-Markov-Chain method, have become increasingly important in the last 2 to 3 decades (Bosch et al., 2006; Mosegaard and Tarantola, 1995). A major advantage of this method compared to deterministic modelling is that a collection of possible solutions is generated, allowing a statistical analysis to compute, for example, model uncertainties. To obtain reliable inversion results, comprehensive information on the petrophysical properties of the model units is required. Therefore, more than 430 rock samples were analyzed with regard to their magnetic susceptibility. Information on the rock density was taken from existing databases (Bär et al., 2020; Weinert et al., 2020b).

\section{Geological Setting}

\subsection{Tectonics}

The URG represents the central part of the European Cenozoic Rift System (ECRIS) (Fig. 1), which consists of several tectonic grabens extending over more than 1,200 km from the Mediterranean to the North Sea (Dèzes et al., 2004; Ziegler, 1992; Ziegler and Dèzes, 2005). The northern URG region has a complex geological structure due to its changeful plate tectonic history from the Early Paleozoic to present (Dallmeyer et al., 1995; McCann, 2008a, 2008b; Ziegler, 1990). The opening of this passive continental rift started in the late Eocene as a reaction to the changing lithospheric stress field in the alpine foreland (Behrmann et al., 2003; Buchner, 1981; Villemin and Bergerat, 1987). Both location and orientation of the URG are largely controlled by reactivation of major fault and shear zones in the basement that were already established during the Variscan orogeny (Edel et al., 2007; Grimmer et al., 2017; Schumacher, 2002). 


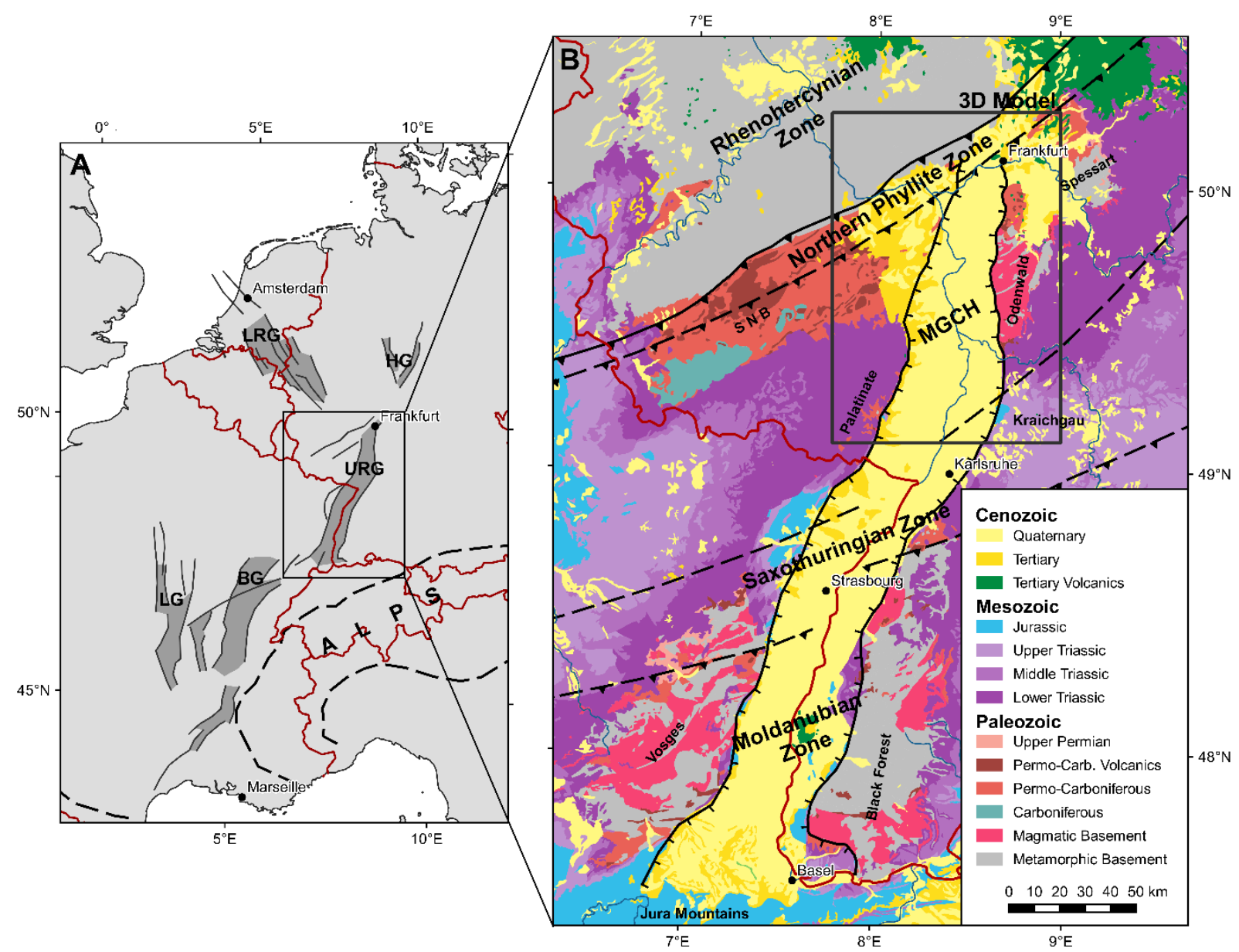

Figure 1: Overview of the study area: (A) simplified map of the European Cenozoic Rift System (modified after Ziegler and Dèzes, 2005), dark grey areas represent rift-related sediment basins; (B) geological map of the URG including boundaries of the Variscan basement units. The black box shows the location of the 3D model. BG = Bresse Graben, HG = Hessian Grabens, LG = Limagne Graben, $L R G$ = Lower Rhine Graben, MGCH = Mid-German Crystalline High, SNB = Saar-Nahe Basin, URG = Upper Rhine Graben .

The crystalline basement in the URG comprises units of the northern side of the Variscan orogenic belt that formed due to the convergence of Laurussia and Gondwana in the Middle Paleozoic (Behr et al., 1984; Franke, 2000; Giese, 1995; Kroner et al., 2008; Zeh and Gerdes, 2010). The paleogeographic environment between these major continents was characterized by various micro terranes and marine basins, also known as Armorican Terrane Assemblage, which had been separated from the northern margin of Gondwana since the Cambrian (Crowley et al., 2000; Franke et al., 2017; Kemnitz et al., 2002). Accordingly, the Variscan mountain range shows strong changes in age, lithology or metamorphic grade mainly perpendicular but also parallel to the main strike direction of NE-SW (Okrusch, 1995; Oncken, 1995). The subduction of the oceanic basins as a result of the advancing convergence led to the formation of extensive volcanic arcs in the Devonian and Carboniferous, exposed e.g. in the Odenwald, Black Forest and Vosges (Okrusch et al., 1995; Stein, 2001; Timmermann and Martin, 2008). The complete closure of the oceans was followed by the main collision phase 
143 in Visean and Namurian times during which the individual terranes were juxtaposed and 144 pronounced continental thrusts were established along the oceanic sutures (McCann et al., 145 2008; Oncken et al., 1999; Skrzypek et al., 2014).

146 Shortly after this collision phase, the regional stress field was reoriented towards an 147 extensional/transtensional regime, resulting in a rapid collapse of the Variscides and opening 148 of numerous NE-SW striking intramontane basins, such as the Saar-Nahe Basin (Henk, 1993a, 149 1993b; Scheck-Wenderoth et al., 2008; Weber, 1995a). These were filled with erosional debris 150 from the surrounding mountain ranges, reaching a cumulative thickness of up to $10 \mathrm{~km}$ (Henk, 151 1992; Schäfer, 1989, 2011). In addition, the rifting was accompanied by widespread felsic to 152 mafic volcanism at the Carboniferous-Permian boundary (Seckendorff et al., 2004). In the 153 Mesozoic, sedimentation was no longer limited to these basins. The Triassic and Jurassic 154 sediments document continuous changes in the depositional environment caused by eustatic 155 sea-level fluctuations in the adjacent Arctic and Tethys Oceans (Feist-Burkhardt et al., 2008). During the Upper Jurassic and Cretaceous, especially the northern URG region was affected by minor volcanism (Böcker, 2015; Martha et al., 2014) and uplift movements, which led to partial erosion of the sediments (Sittler, 1969, 1992). Consequently, the age of the youngest preserved Mesozoic formations increases continuously from south to north, with no more Mesozoic formation preserved in the northernmost part of the URG.

The Cenozoic formation of the URG is usually divided into two main phases (Behrmann et al., 2003; Buchner, 1981; Dèzes et al., 2004; Villemin et al., 1986). During the first phase from the Late Eocene to the Early Miocene, most of the crustal extension took place. In this period, the main horizontal stress direction $S_{H}$ was roughly NNE-SSW. In the second phase from the Miocene to the present, the stress field was reoriented with $S_{H}$ mainly trending in NW-SE direction, leading to sinistral reactivation of faults zones parallel to the main graben axis (Buchmann and Connolly, 2007; Homuth et al., 2014). While a transtensional regime in the northern URG led to subsidence of the sedimentary basin, the southern part was affected by transpression (Illies and Greiner, 1979; Rotstein and Schaming, 2011). Latter caused uplift in the Middle and Late Miocene, resulting in erosion or non-deposition of sediments and thus in a hiatus of about $10 \mathrm{Ma}$ (Geyer et al., 2011; Grimmer et al., 2017). All sedimentary units as well as the Variscan basement in this region are affected by intensive faulting with vertical offsets between fault blocks of partly several hundred meters. The total horizontal extension ranges from about 5 to $8 \mathrm{~km}$ and the total vertical offset reaches up to $4 \mathrm{~km}$ (Grimmer et al., 2017; Meier and Eisbacher, 1991). 
of the URG has been postulated, which may have already developed during the juxtaposition of Variscan terranes in the Visean (Edel et al., 2007; Edel and Weber, 1995; Schumacher, 2002). According to the authors, this sinistral transform system had a considerable impact on past and recent deformation in the URG due to multiple reactivations. Thus far, however, the shear zone has not been detected in any boreholes, meaning that no definite statements can be made about its exact location, geometry and structure.

\subsection{Pre-Permian Crystalline Basement}

A first definition of the Variscan basement in Central Europe was developed by Suess (1926) and Kossmat (1927) and has been continuously expanded since then. The following main units can be distinguished from north to south: Rhenohercynian Zone, Northern Phyllite Zone, MidGerman Crystalline High (MGCH), Saxothuringian Zone and Moldanubian Zone (Figs. 1 \& 2). In the northern URG, the MGCH makes up the largest part of the basement. It is traditionally seen as the deeply exposed northern active margin of the Armorican Terrain Assemblage, that formed between the Late Devonian and Mid-Carboniferous as a result of the southward subduction of the Rheic and Rhenohercynian Oceans (Hirschmann, 1995; Zeh and Gerdes, 2010).

The largest and hence most important outcrop of the MGCH in the URG region is the crystalline Odenwald (Fig. 2), which is usually divided into the eastern, metamorphic Böllstein Odenwald and the western, mainly plutonic Bergsträßer Odenwald (Krohe and Willner, 1995; Stein, 2001). Both units are separated by the Otzberg Zone, a crustal-scale sinistral strike-slip fault. The Böllstein Odenwald consists of a granitic and granodioritic orthogneiss core, surrounded by metapelitic schists. According to Reischmann et al. (2001), the age of the protoliths is $405 \pm 3 \mathrm{Ma}$, thus presumably representing relics of a Silurian/Early Devonian magmatic arc (Altenberger and Besch, 1993). Due to the great lithological similarities, the Spessart is most likely the northeastern extension of the Böllstein Odenwald (Weber, 1995b). The Bergsträßer Odenwald consists mainly of mafic to felsic plutonic rocks, that are intruded into Early Paleozoic metasediments, the so-called 'Schieferzüge' (Krohe, 1991, 1992). This unit is again subdivided into the Frankenstein Complex, the Flasergranitoid Zone and the Southern Plutons, each separated by large strike-slip fault zones. The first two units have a very heterogeneous structure due to numerous local intrusions. The southern Bergsträßer Odenwald, in comparison, is dominated by large and homogeneous plutons (Weschnitz, Tromm, Heidelberg pluton). From north to south, the age of the intrusions is continuously decreasing from about $360 \mathrm{Ma}$ in the Frankenstein Complex to about $325 \mathrm{Ma}$ in the Heidelberg area (Kirsch et al., 1988; Kreuzer and Harre, 1975). Likewise, the rock composition is rather mafic in the north and becomes felsic towards the south (Laue et al., 1990; Okrusch et al., 1995). The 
214 Bergsträßer Odenwald is hence interpreted as a transition zone from an island arc to an active

215 continental margin (Altherr et al., 1999).

216 In the Palatinate west of the URG, surface exposures of the MCGH are very limited (Flöttmann 217 and Oncken, 1992; Laue and Reischmann, 1994). The largest outcrop is in Albersweiler, where 218 orthogneisses derived from $369 \pm 5 \mathrm{Ma}$ old magmatic protoliths are strongly intercalated with 219 metamorphosed mafic dykes (Stellrecht, 1971; Anthes and Reischmann, 1997). In the nearby 220 Waldhambach quarry, granodiorite is predominant alongside amphibolite and gneiss. 221 Metagreywackes and metapelites were found at several locations, e.g. in Burrweiler, Neustadt 222 and Weiler. Granitoid intrusions with an age of about $340 \mathrm{Ma}$ are present in the Schwarzbach 223 valley, the Kaiserbach valley and Edenkoben (Frenzel, 1971). Apart from the above-mentioned 224 outcrops, only a few deep boreholes penetrate the basement in the northern URG (Bär, 2012). 225 Granitoids are predominant at most locations and additionally, amphibolites were drilled in the 226 wells Weiterstadt 1 and WIAG Hessen 5 . In the well Worms 3 , the basement consists of 227 fractured gneisses and cataclasites that might be related to the adjacent Worms Fault Zone 228 within the URG.

229 In the north, the MGCH borders the Northern Phyllite Zone, which is exposed in the southern 230 Taunus and Hunsrück (Anderle et al., 1995; Klügel, 1997). This zone comprises a tectonic 231 mélange of about $2 / 3$ sedimentary and $1 / 3$ volcanic rocks that were overprinted by pressure232 dominated greenschist-facies conditions. The boundary between the two units is a major 233 continental thrust, but the exact location is still unknown due to the complete sedimentary 234 cover. Xenoliths from the Vogelsberg can be assigned to both the Northern Phyllite Zone and 235 the $\mathrm{MGCH}$, allowing to trace the tectonic contact beneath the Miocene volcanics (Martha et 236 al., 2014).

237 In the south, the MGCH transitions into the Saxothuringian Zone, which crops out in the 238 northern Black Forest and Vosges (McCann et al., 2008). This zone comprises a 239 metamorphosed, early Paleozoic shelf sequence that overlies a Neoproterozoic gneiss 240 basement. The style of the boundary between $\mathrm{MGCH}$ and Saxothuringia is still under debate, 241 but the location can be inferred from the gravity anomalies (Edel and Fluck, 1989; Giese, 242 1995), as the latter is characterized by a distinct high density. 


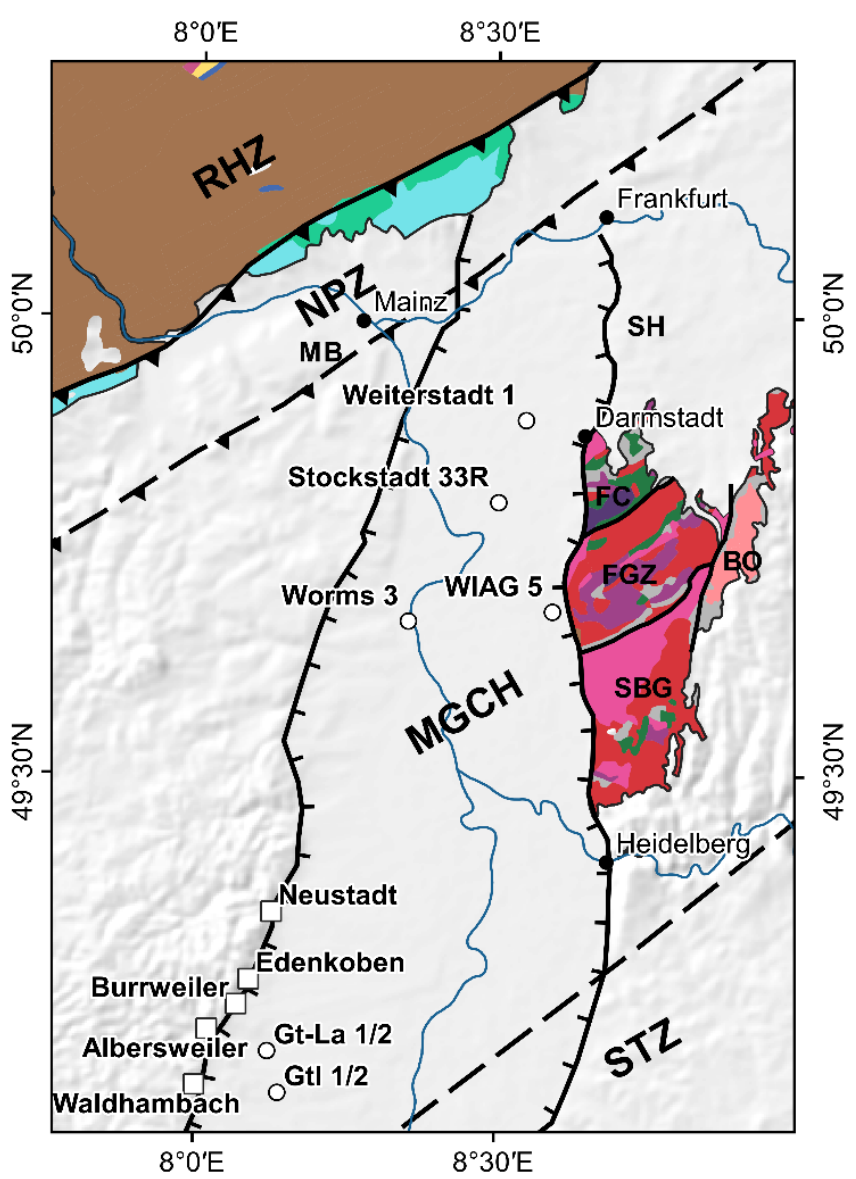

Magmatic Basement

Granite

Granodiorite

Diorite

Gabbro

Metamorphic Basement

low-grade Metasediments Phyllite

Sericite-Gneiss

Amphibolite

Paragneiss, Mica Schist

Orthogneiss

local basement outcrops

○ deep wells

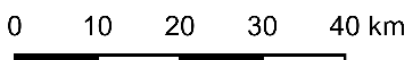

Figure 2: Generalized map illustrating the basement outcrops in the northern URG region including the available wells intersecting the basement. $\mathrm{BO}=$ Böllstein Odenwald, $\mathrm{FC}=$ Frankenstein Complex, FGZ = Flaser-Granitoid Zone, $\mathrm{MB}=$ Mainz Basin, $\mathrm{MGCH}=$ Mid-German Crystalline High, NPZ = Northern Phyllite Zone, RHZ = Rhenohercynian Zone, SBG = Southern Bergsträßer Granitoids, SH = Sprendlinger Horst, STZ = Saxothuringian Zone.

\subsection{Post-Variscan Sediments}

The sedimentary cover and especially the Cenozoic infill of the northern URG was, in contrast to the crystalline basement, well studied by the extensive hydrocarbon exploration since the 1950s (Reinhold et al., 2016; Boigk, 1981). An overview of the distribution and lithological properties of the most important horizons is given in the following.

The Permo-Carboniferous is overlying the crystalline basement of the northern URG on a large area. It mainly consists of erosional debris from the Variscan mountain chain and intercalated volcanics, which were deposited in several NE-SW oriented transtensional basins, like the Saar-Nahe Basin, the Hessian Basin or the Kraichgau Trough (Aretz et al., 2016; Henk, 1993b; Schäfer, 1989; Weber, 1995a). Close to the Hunsrück border fault, these deposits reach their maximum thickness of more than $6.5 \mathrm{~km}$. The Saar-Nahe Basin continues to the northeast under the Cenozoic cover of the northern URG up to the Sprendlinger Horst (Molenaar et al., 
2015; Müller, 1996), but the thickness is much smaller here (Marell, 1989). The volcanic formations consist of rhyolite, andesite and basalt, which occur in form of dikes and lava flows

263 (Hertle, 2003; Stollhofen, 1998). They are heterogeneously distributed in the URG region and 264 an accurate 3D representation is difficult due to the poor well data availability.

265 The Buntsandstein mainly consists of clastic sedimentary rocks, which reflect the terrestrial 266 conditions in the lower Triassic. This succession is dominated by uniform red-brown or light 267 gray sandstone sequences with alternating fine- and coarse-grained layers (Backhaus, 1974). 268 The Buntsandstein is exposed over a large area in the Palatinate and eastern Odenwald 269 (Backhaus, 1975; Backhaus and Heim, 1995; Backhaus and Schwarz, 2003; Dachroth, 1988). 270 In the URG, however, the horizon is only found approximately south of Worms at a depth of 271 more than $2.5 \mathrm{~km}$ and has a maximum thickness of about $500 \mathrm{~m}$ (Bär, 2012; Boigk and 272 Schöneich, 1974). Younger Triassic sediments only occur south of Heidelberg and their total 273 thickness is usually less than $500 \mathrm{~m}$ (Sokol et al., 2013). The Muschelkalk consists of marine 274 limestones and dolostones, documenting a full marine sedimentary environment. In contrast, 275 the Keuper, is dominated by claystones and sandstones, which are interbedded by evaporite 276 layers.

277 With the opening of the URG in the Eocene, an important sedimentary basin was again 278 established, in which marl, sandstones, carbonates, and evaporites were alternatingly 279 deposited (Doebl, 1967; Sissingh, 1998). The sedimentary conditions were predominantly 280 limnic or brackish, but at least two marine transgressions are also documented. Almost in the 281 entire northern URG, the Cenozoic graben infill has a thickness of more than $2000 \mathrm{~m}$. The 282 highest thickness of $3300 \mathrm{~m}$ is reached close to the eastern margin between Worms and 283 Heidelberg (Doebl and Olbrecht, 1974).

\section{Material and Methods}

\subsection{Data}

\subsection{Geological Information}

287 The initial 3D model of the northern URG was mainly developed by compiling existing structural 288 models (Fig. 3). In the inner part of the graben as well as in the remaining area of Hesse, the 289 detailed models of the Interreg GeORG and Hessen 3D (1.0 and 2.0) projects were used 290 (Arndt, 2012; Bär et al., 2016; Sokol et al., 2013; Weinert et al., 2021, in prep.), which are 291 based on 2D reflection seismic data, borehole data, geological profiles and isopach maps. At 292 the southern border of Hesse, where the study areas of these projects partly overlap, the depth 
of specific horizons can deviate by several hundred meters. In order to harmonize these different results, also the recently reprocessed and reinterpreted DEKORP $9 \mathrm{~N}$ line was incorporated (Bär et al., 2021, in prep.). Based on the GeORG and Hessen 3D models, a simplified fault model containing about a dozen of the largest faults in the northern URG region was furthermore developed. For the areas outside the URG that are not located in Hesse, information on horizon depths was extracted from the models of Freymark et al. (2015) and Freymark et al. (2020). Due to the lower density of the input data there, the model resolution is also lower but still acceptable, since the main focus was not on the graben shoulders where outcrops provide sufficient details on the crystalline basement. Additionally, the depth of the Moho and lower crust from the Freymark et al. (2020) model was used to calculate a regional gravity field (see section 3.2.1 for more details).

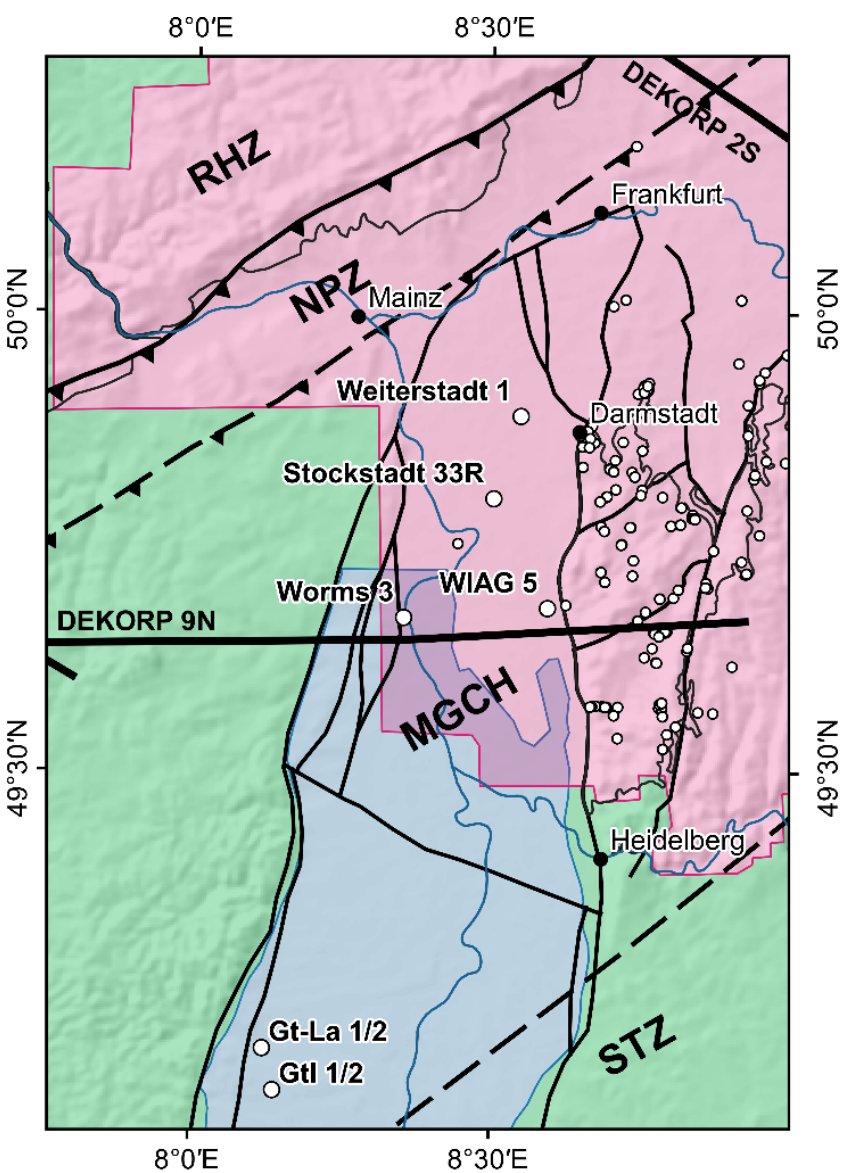

3D models
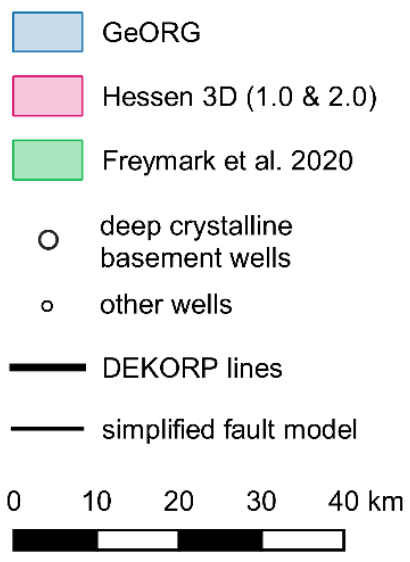

Figure 3: Overview of the structural input data for the 3D modelling of the northern URG. RHZ = Rhenohercynian Zone, NPZ = Northern Phyllite Zone, MGCH = Mid-German Crystalline High, STZ = Saxothuringian Zone, URG = Upper Rhine Graben.

Apart from the mentioned modelling results, geological contacts and outcrops of large fault zones at the surface were digitized from various geological maps. To validate the initial model and the inversion result, especially with regard to the basement lithology, a database provided by the Hessian State Agency for Nature Conservation, Environment and Geology (HLNUG) 
containing about 170 boreholes deeper than 70 m was used. However, most of the wells are

313 located in the Odenwald or on the Sprendlinger Horst outside the URG. Therefore, information 314 on crystalline rocks beneath the Permo-Triassic and Cenozoic graben infill is very sparse. A 315 summary of the deep crystalline basement wells in the northern URG is given in Tab. 1.

316 Table 1: Summary the deep wells in the northern URG reaching the crystalline basement.

\begin{tabular}{|c|c|c|c|}
\hline Well name & $\begin{array}{l}\text { Depth to top } \\
\text { basement } \\
{[\mathrm{m}]}\end{array}$ & Basement lithology & Petrophysical data available \\
\hline Insheim GTI 1/2 & ?not published & granite & - \\
\hline Landau GtLa 1/2 & 2487,2550 TVD & granite & - \\
\hline Stockstadt 33R & $2245 \mathrm{MD}$ & granodiorit & Frey et al. (2020), Weinert et al. (2020a) \\
\hline Weiterstadt 1 & $2505 \mathrm{MD}$ & granite, amphibolite & Frey et al. (2020), Weinert et al. (2020a) \\
\hline WIAG Hessen 5 & $2180 \mathrm{MD}$ & $\begin{array}{l}\text { granite, } \\
\text { amphibolites }\end{array}$ & - \\
\hline Worms 3 & 2204 MD & fractured gneiss & Frey et al. (2020), Weinert et al. (2020a) \\
\hline
\end{tabular}

\subsubsection{Gravity and Magnetic Data}

319 For the gravity modelling, a compilation of terrestrial point measurements provided by the Leibniz Institute for Applied Geophysics (LIAG), the Hessian Administration for Soil Management and Geoinformation (HVBG) and the State Agency for Surveying and Geo Base Information Rhineland-Palatinate (LVermGeo) was used. In the study area, the combined dataset consists of more than 7,000 stations with a distance between a few hundred meters and $5 \mathrm{~km}$. Consequently, the resolution of the observed gravity anomalies varies considerably across the northern URG and the adjacent areas. A complete Bouguer correction has been carried out with a reference density of $2.67 \mathrm{~g} / \mathrm{cm}^{3}$. From this point data, a Bouguer anomaly grid with a nominal resolution of $500 \mathrm{~m}$ was calculated by applying a minimum curvature approach (Fig. 4A).

329 The values of the gravity anomalies range from about -40 to $+20 \mathrm{mGal}$. The inner part of the

330 URG is characterized by a distinct negative anomaly that can to a large extent be explained 331 by the relatively light sedimentary infill. The largest anomaly highs represent rather local 332 features and are located at the mafic Frankenstein Complex and the Mainz Basin. There are 333 moreover some broader highs, for example in the Kraichgau and the Palatinate. 
334 The total magnetic field anomaly grid shown in Fig. 4B is a compiled dataset of several surface

335 and aero-geophysical surveys that have been carried out since the 1960s (Gabriel et al., 2011).

336 Airborne measurements have been performed by PRAKLA-SEISMOS between 1965 and 1971

337 with a line-spacing of 2,200 $\mathrm{m}$ and a point distance of approximately $65 \mathrm{~m}$. Besides, the LIAG

338 and predecessor institutes conducted supplementary magnetic surveys. As for the gravity field,

339 there are therefore lateral variations of the resolution.

340 The anomalies vary from about $-150 \mathrm{nT}$ to more than $300 \mathrm{nT}$ in the northern URG. The 341 magnetic field in the northern URG is dominated by SW-NE striking features which are most 342 likely caused by the Variscan units. Their pronunciation possibly results from the steeply 343 dipping foliation of the basement units, as observed, for example, in the Flasergranitoid Zone. 344 In addition, a laterally heterogeneous upper crust is indicated by the abundant local variations. 345 The strongest magnetic high coincides with the above-mentioned gravity anomaly at the 346 Frankenstein Complex. This anomaly extends to the SW underneath the graben infill and might 347 be furthermore associated with the magnetic high at the southeastern Palatinate. Another 348 broad positive anomaly is located in the area of the southern Odenwald plutons. Magnetic 349 anomaly lows are mostly concentrated in an SW-NE trending belt at the northern and western 350 margin of the $\mathrm{MGCH}$. Another distinct negative anomaly is connected to the Flasergranitoid 351 Zone and the Böllstein Odenwald.

352 The post-Varican deposits can generally be considered magnetically transparent due to their 353 Iow magnetic susceptibility (Tab. 2; Frey et al., 2020). Excluded from this assumption are the 354 Permo-Carboniferous volcanic-sedimentary horizons and the scattered tertiary volcanics 355 (Vogelsberg, Roßdorf, Otzberg, Messel). Especially in the Saar-Nahe Basin, at the Vogelsberg 356 and at the northern margin of the URG, these volcanics are source for strong and short 357 wavelength magnetic anomalies, which are also partly linked to positive gravity anomalies (e.g. 358 Mainz Basin). 

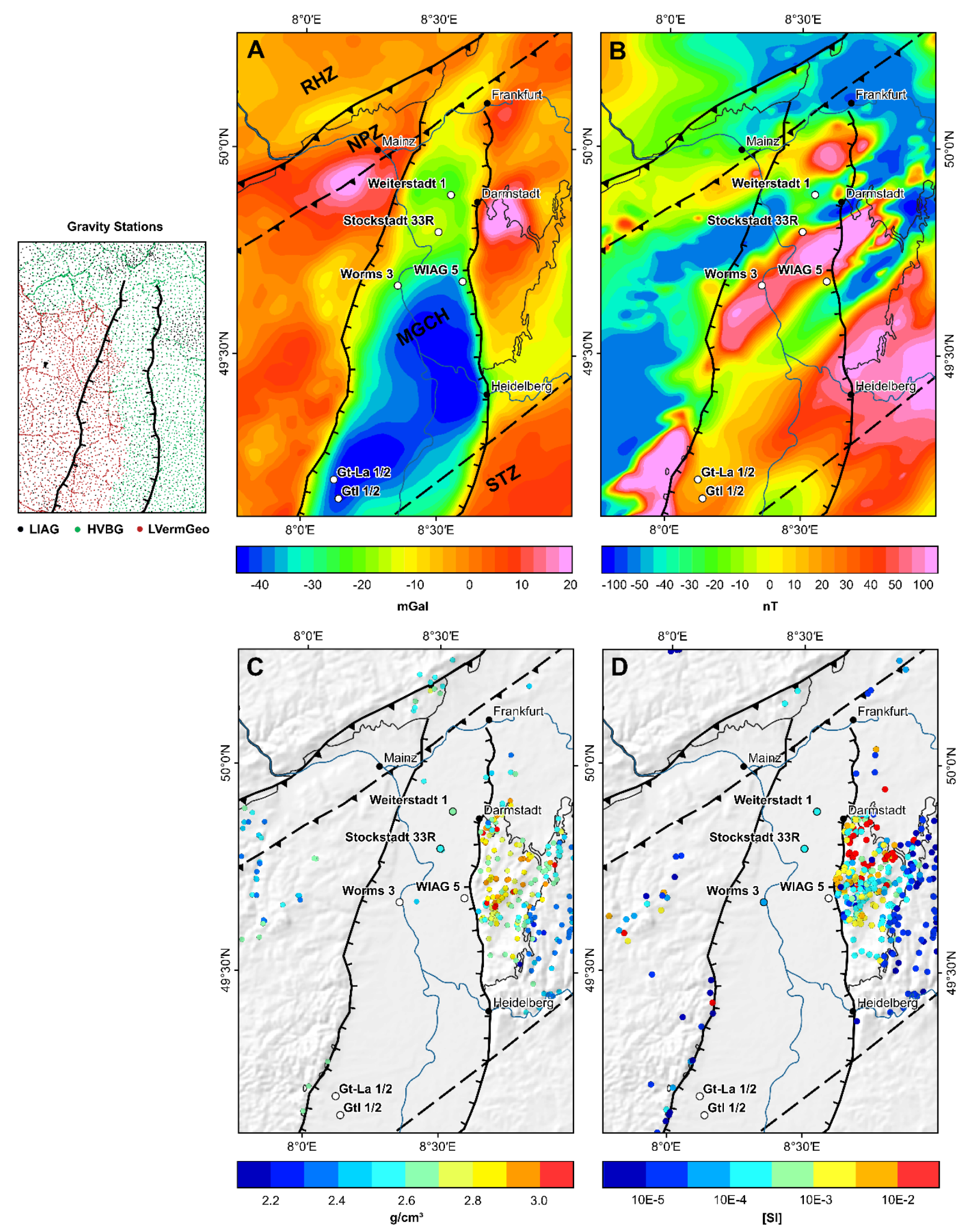

Figure 4: Overview of the geophysical and petrophysical input data: (A) Bouguer anomalies in the northern URG region including map of the used gravity stations; (B) magnetic anomalies; (C) sample locations of bulk density measurements; (D) sample locations of magnetic susceptibility measurements. RHZ = Rhenohercynian Zone, NPZ = Northern Phyllite Zone, MGCH = Mid-German Crystalline High, STZ = Saxothuringian Zone, URG = Upper Rhine Graben. (Data Basis and Copyright of the gravity and magnetic data: Leibniz Institut für Angewandte Geophysik, Hannover; Hessische Verwaltung für Bodenmanagement und Geoinformation; Geobasisinformationen der Vermessungs- und Katasterverwaltung Rheinland-Pfalz). 
368 Comprehensive data on the rock density and magnetic susceptibility of the common lithologies 369 in the northern URG were collected in order to attribute realistic petrophysical properties to the geological units in the gravity and magnetic models. Density measurements have been conducted in several previous studies and the results were compiled in the $\mathrm{P}^{3}$ database (Bär et al., 2020). A summary of the petrophysical parameters of the $\mathrm{MGCH}$ is additionally given in the database of Weinert et al. (2020a, b). The density distribution of the Cenozoic sediments was inferred from borehole logs of the five deep wells Eich 22, Eich 27, Eich H1, Weiterstadt 1 and Worms 3 in the northern URG. Besides, measurements of the magnetic susceptibility were done with the SM-30 handheld device from GeoResults. In total about 430 samples of various geological units provided by the Institute for Rock Conservation (IfS) in Mainz were analyzed (Frey et al., 2020). Figs. 4C \& 4D show the distribution of all density and susceptibility measurements in the study area. In case, very little or no information was available, e.g. in the Saxothuringian or Rhenohercynian Zones, values from the models of Freymark et al. (2015) and Edel and Schulmann (2009) were adopted. samples.

\begin{tabular}{lcc}
\hline Rock type & Mean density & $\begin{array}{c}\text { Mean Magnetic } \\
\text { susceptibility }\end{array}$ \\
\hline Granite & $2.65 \pm 0.028$ & $0.0020 \pm 0.0043$ \\
Granodiorite & $2.72 \pm 0.062$ & $0.0017 \pm 0.0020$ \\
Diorite & $2.80 \pm 0.052$ & $0.0062 \pm 0.0094$ \\
Gabbro & $2.90 \pm 0.068$ & $0.0221 \pm 0.0284$ \\
Low-grade metasediments & $2.73 \pm 0.088$ & - \\
Gneiss & $2.65 \pm 0.055$ & $0.0012 \pm 0.0041$ \\
Amphibolite & $2.91 \pm 0.125$ & $0.0089 \pm 0.0114$ \\
Permian and Cenozoic volcanics & $2.72 \pm 0.147$ & $0.0065 \pm 0.0089$ \\
Permian and Triassic sandstones & $2.46 \pm 0.116$ & $1.9 \mathrm{E}-5 \pm 2.2 \mathrm{E}-5$ \\
Cenozoic sandstones & $2.25 \pm 0.104$ & - \\
\hline
\end{tabular}

Tab. 2 summarizes petrophysical parameters for the main rock types. Because the model units (Tab. 3) are lithologically heterogeneous, a volumetric approach to calculate the model parameters was applied. This means that the parameters from Tab. 2 were weighted by the 
area fraction of the rock type in the respective unit. For the Permo-Carboniferous, Mesozoic and Cenozoic sediments, density-depth gradients were defined to account for the compaction caused by the increasing load.

For all basement units, a parameter optimization was performed before inversion to achieve a good initial fit between the forward modelled and observed potential fields. An optimization is required because, apart from the Odenwald and Saar-Nahe Basin, only very few outcrops of the crystalline basement are available, thus the distribution of density and magnetic susceptibility is not sufficiently constrained. Moreover, samples from quarries and natural outcrops are not necessarily representative for the entire model unit due to e.g. weathering and exhumation effects. A summary of the initial, optimized and inverted properties is given in Tab.4.

\subsection{Methods}

\subsubsection{D Geological Forward Modelling}

The 3D structural modelling of the northern URG was performed with the commercial platform GeoModeller (Calcagno et al., 2008; Guillen et al., 2008; Lajaunie et al., 1997), which enables the development of complex geological models based on different input data and allows the integration and inversion of geophysical measurements. The software uses the principles of potential field interpolation and considers both structural data and stratigraphic rules to construct the model (Calcagno et al., 2008; Lajaunie et al., 1997). Geological contacts are considered as iso-potential surfaces and the orientation of a horizon corresponds to the gradient of the field. This ensures that a consistent and smooth model is created in agreement with defined geological rules, e.g. chronology and relations between the geological events.

The model domain has a size of $90 \mathrm{~km}$ in E-W direction, $130 \mathrm{~km}$ in N-S (see Fig. 1). It covers a large part of the graben shoulders, since the main outcrops of the crystalline basement are located here. The top surface of the model is the DEM given by the Shuttle Radar Topography Mission (SRTM) (van Zyl, 2001) with an original resolution of one arc second and was resampled to a cell size of $500 \mathrm{~m}$ to reduce the computational effort.

To separate the different sources of the gravity field, three distinct forward models, a regional, a sedimentary and a basement model of the northern URG were developed that cover different depth intervals of the lithosphere. A summary of all model units is given in Tab. 3 . The individual gravitational effects of the regional and sedimentary model were forward calculated and subtracted from the observed field. This approach, also known as stripping (e.g. Hammer, 1963), results in a residual map of the Bouguer anomalies (Fig. 7) that provides direct insight 
421 into the density distribution of the crystalline basement. Based on this product as well as the

422 magnetic anomalies and structural data, the initial basement model was created.

423 The basement model consists of 10 units, whereby the MGCH was divided into 7 subunits 424 (Fig. 5). According to the surface outcrops, the 4 units Frankenstein Complex, Flasergranitoid 425 Zone, Southern Odenwald and Böllstein Odenwald were defined. To explain the positive 426 gravity and magnetic anomaly in the Southeast Palatinate, an additional body with similar 427 properties as the Frankenstein Complex was introduced, referred to as the Southwestern 428 Magnetic Body in the following. The northwestern part of the $\mathrm{MGCH}$ was modelled as a 429 separate body, which is characterized by a high density and low susceptibility, analogously to 430 the Saxothuringian Zone. However, due to the scarcity of wells and outcrops, little information 431 is available about this zone's composition. Finally, a granitoid body of reduced density was 432 defined north of the Frankenstein Complex, which explains the local gravity low and is 433 evidenced by small outcrops and boreholes at the Sprendlinger Horst.

434 In areas where the geological contacts are not exposed, the model geometry is based on the 435 magnetic and gravity anomalies or on existing interpretations (e.g. Franke, 2000; Will et al., 436 2015). The boundaries between the main tectonic units were modelled as southeastwards 437 dipping thrusts according to the DEKORP 2S and 9N lines (Behr and Heinrichs, 1987; Jodocy 438 and Stober, 2010; Oncken, 1998). The interfaces between the plutonic bodies of the MGCH 439 are generally assumed to be steeply dipping. 
Table 3: Summary of the three forward models including the modelled units and their main lithology.

\begin{tabular}{|c|c|c|c|}
\hline Model & \multicolumn{2}{|c|}{ Horizon } & Main lithology \\
\hline \multirow{5}{*}{ 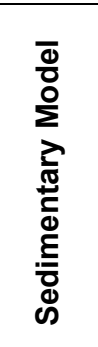 } & \multicolumn{2}{|c|}{ Cenozoic } & $\begin{array}{l}\text { sandstones, claystones, marl, subordinate carbonates } \\
\text { and evaporites }\end{array}$ \\
\hline & \multicolumn{2}{|c|}{ Keuper } & sandstones, claystones, subordinate evaporites \\
\hline & \multicolumn{2}{|c|}{ Muschelkalk } & limestones, dolostones \\
\hline & \multicolumn{2}{|c|}{ Buntsandstein } & sandstones, subordinate claystones \\
\hline & \multicolumn{2}{|c|}{ Permo-Carboniferous } & $\begin{array}{l}\text { sandstones, conglomerate, subordinate claystones, } \\
\text { felsic to mafic volcanic rocks }\end{array}$ \\
\hline \multirow{2}{*}{ 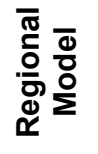 } & \multicolumn{2}{|c|}{ Lower Crust } & mafic and metamorphic rocks \\
\hline & \multicolumn{2}{|c|}{ Lithospheric Mantle } & ultrasmafic rocks \\
\hline \multirow{10}{*}{ 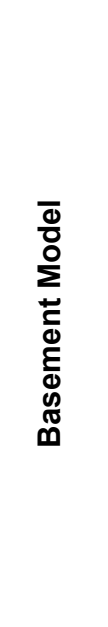 } & \multicolumn{2}{|c|}{ Rhenohercynian Zone } & low-grade metasediments \\
\hline & \multicolumn{2}{|c|}{ Northern Phyllite Zone } & metasediments, metavolcanics \\
\hline & \multirow{7}{*}{ 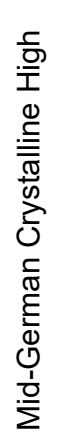 } & Frankenstein Complex & gabbros, amphibolites, gneiss, subordinate granitoids \\
\hline & & Flasergranitoid Zone & granitoids, diorites, amphibolite, gneiss \\
\hline & & Southern Plutons & granitoids, subordinate gneiss and amphibolites \\
\hline & & Böllstein Odenwald & orthogneiss, subordinate paragneiss and granitoids \\
\hline & & Northern Granitoids & granitoids \\
\hline & & Southwestern Magnetic Body & very uncertain, similar to Frankenstein Complex \\
\hline & & Northwestern MGCH & gneiss, metasediments \\
\hline & \multicolumn{2}{|c|}{ Saxothuringian Zone } & gneiss, metasediments \\
\hline
\end{tabular}

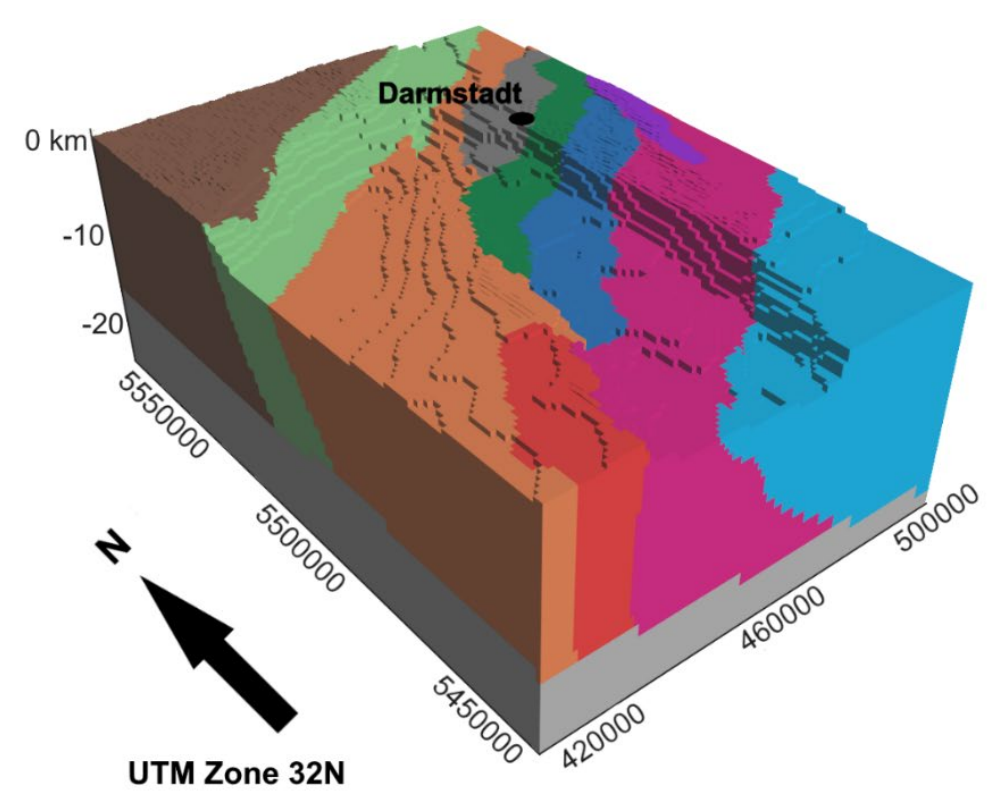

Rhenohercynian Zone Northern Phyllite Zone Saxothuringian Zone Lower Crust

Böllstein Odenwald

Northern Granitoids

NW Metamorphic MGCH

SW Magnetic Body

443 Figure 5: Illustration of the 3D forward model of the crystalline basement in the northern URG region. 
445 A structure-coupled joint inversion of gravity and magnetic data has been carried out to 446 improve the developed basement forward model and to gain detailed insights about the spatial 447 distribution of petrophysical properties. In contrast to separate inversion of the two potential 448 fields, this approach reduces the non-uniqueness of the modelling result. A stochastic inversion 449 algorithm based on a Monte-Carlo simulation is implemented in GeoModeller. The inversion 450 explores a large number of variations of the structural and petrophysical models. Those realization which reduce the inconsistencies between the calculated and observed anomalies are selected and allow a statistical evaluation of the inversion results. A detailed description of the inversion scheme is given in Guillen et al. (2008). In the following and in Fig. 6, the specific workflow applied in this study is summarized:

\section{A priori model}

The basement forward model served as the a priori information for the inversion. The parametrization of the individual units is constrained by the petrophysical data and the optimized densities and magnetic susceptibilities shown in Tab. 4 were used as starting values. The parameters of the sediments and the lower crust were set to constant reference values (density $=2.67 \mathrm{~g} / \mathrm{cm}^{3}$ and magnetic susceptibility $=0$ ) as their effect was already considered during the forward modelling.

\section{Model discretization}

For the inversion, the continuous horizons were converted into a discrete cuboid voxel model. The cell size has to be small enough to represent the geological structures adequately. It should be noted, however, that the computational effort increases of course with a growing number of voxels. Therefore, a uniform cell size of $1 \times 1 \mathrm{~km}$ was used in the horizontal plane. In vertical direction, a varying cell size was defined. To take into account the topographic effects, a relatively small cell height of $50 \mathrm{~m}$ was used above the mean sea level. Below, the cell height increases gradually from $500 \mathrm{~m}$ to about $1,500 \mathrm{~m}$ towards the base. Consequently, the model consists in total of about 540,000 voxels.

\section{Calculation of gravity and magnetic anomalies}

The geophysical response of the initial density and susceptibility model is calculated by summing the effect of each voxel. The calculation was done on a constant height of $1,000 \mathrm{~m}$ a.s.l. to minimize model artifacts, for example, due to the discretization. 


\section{Disturbing the model}

477

478

479

480

481

482

483

484

485

486

487

488

489

490

491

492

493

494

495

496

497

498

During each iteration, either petrophysical properties or the lithology of one cell are randomly changed according to the defined probability density functions. The magnitude of lithology changes is controlled by the parameters shape ratio, volume ratio and communality, which were set to moderate values according to the documentation of GeoModeller (Intrepid Geophysics, 2017). Moreover, the top of the basement and lower crust were fixed so that only the units within the upper crystalline crust could be modified.

\section{Recalculation of the geophysical effect}

Based on the disturbed model, gravity and magnetic anomalies are recalculated.

\section{Likelihood of the disturbed model}

The likelihood of the disturbed model $L\left(m_{\text {dis }}\right)$ is calculated as a function of the misfit with the observed data and compared to the likelihood of the current model $L\left(m_{\text {cur }}\right)$. If $L\left(m_{\text {dis }}\right)>L\left(m_{\text {cur }}\right), m_{\text {dis }}$ is accepted and becomes $m_{\text {cur }}$ in the next iteration. If $L\left(m_{\text {dis }}\right) \leq L\left(m_{\text {cur }}\right)$, $m_{\text {dis }}$ might still be accepted, depending on a randomly sampled number, to ensure that the inversion does not get stuck in local minima. All accepted models are stored in a separate file.

\section{Iteration and computing inversion result}

The algorithm starts over with step 4 until 500 million iterations have been calculated. This high number of realizations is required to visit every cell several times. Afterwards, all accepted models are combined to a summary model that contains information about the mean density and susceptibility, the standard deviation, and the most probable model unit of a cell. 


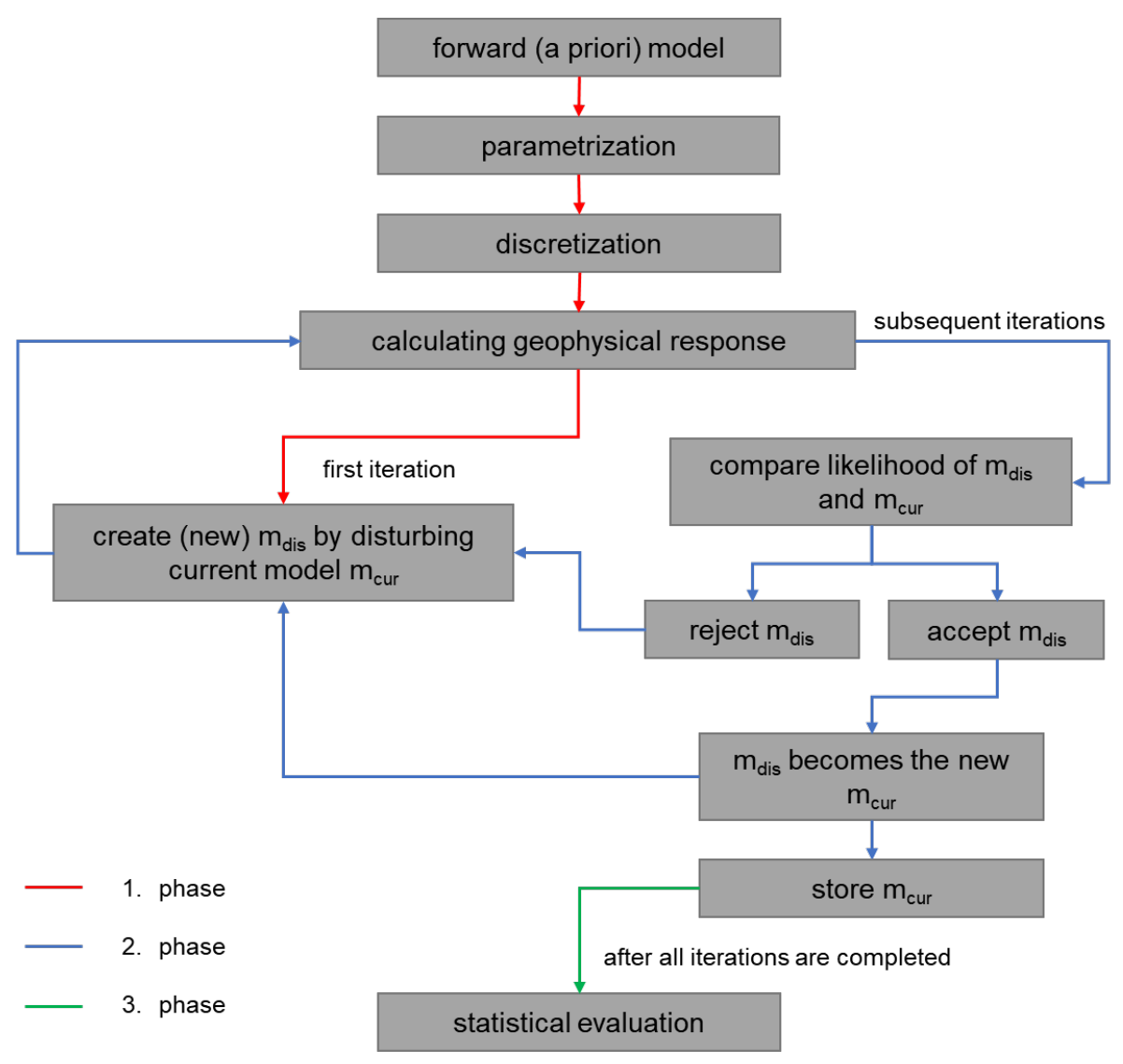

500 Figure 6: Generalized workflow of the stochastic joint inversion of gravity and magnetic data.

\section{Results}

\section{4.1 Residual Gravity Anomalies}

503 A residual Bouguer Anomaly map of the northern URG was generated by stripping the 504 sedimentary and regional gravity effect from the observed data (Fig. 7). As a result, the field is 505 no longer dominated by the distinct negative anomaly along the graben created by the 506 Cenozoic infill. Instead, this product mainly represents features of the crystalline basement. As 507 with the magnetic data, NE-SW striking features can be traced across the URG that are caused 508 by the Variscan belt. 

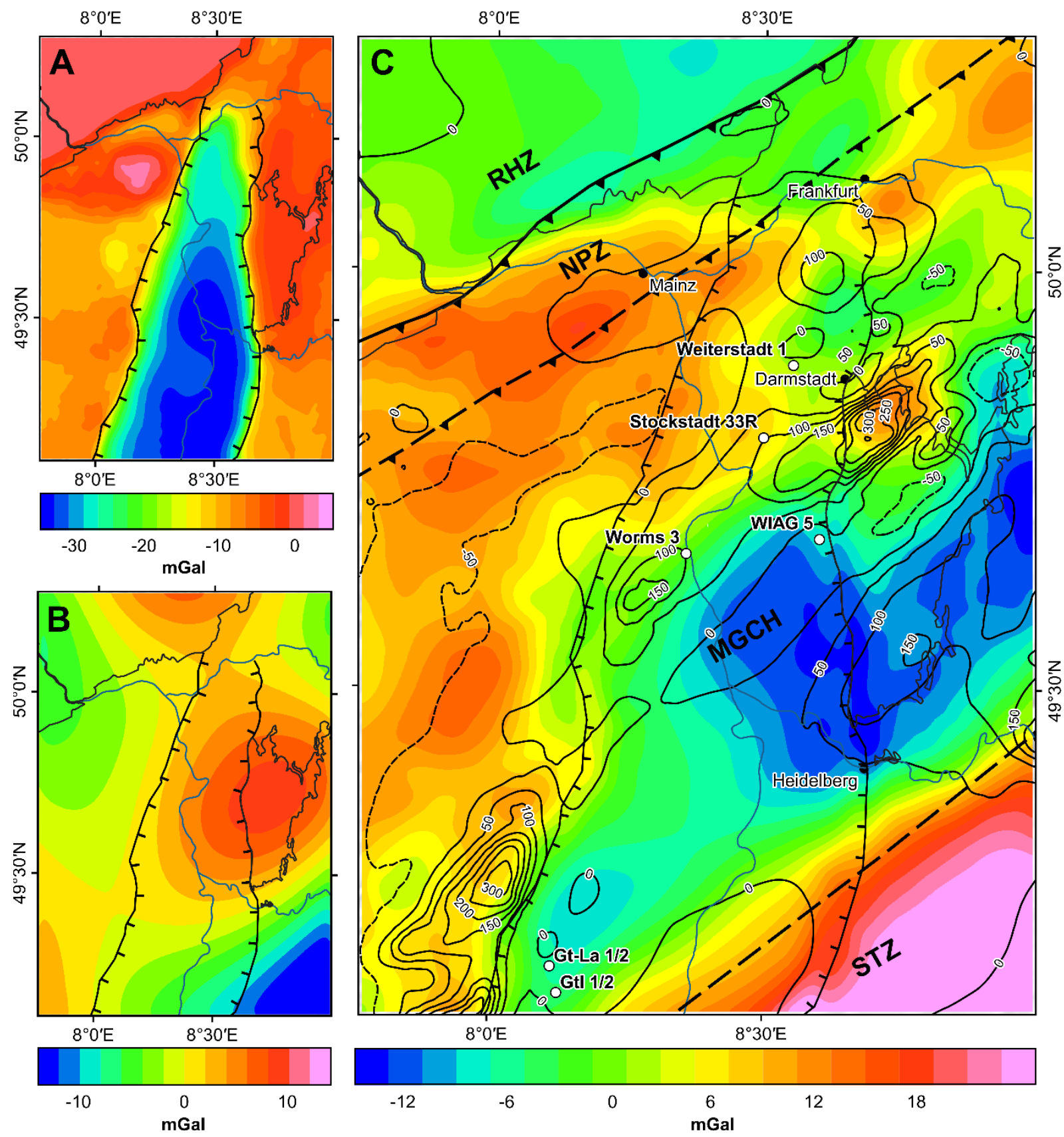

Figure 7: Separation of the gravity anomalies: (A) forward calculated gravitational effect of the sediments in the northern URG region; (B) forward calculated regional gravity field; (C) residual Bouguer anomalies. The isolines represent the magnetic anomalies after a reduction to the magnetic pole. RHZ = Rhenohercynian Zone, NPZ = Northern Phyllite Zone, MGCH = Mid-German Crystalline High, STZ = Saxothuringian Zone.

514 The strongest high of the residual anomalies is now located in the Saxothuringian Zone, which consists of a dense metamorphic crust and is clearly distinguishable from the granitoids of the southern MGCH. Another broad high extends over the northern/northwestern MGCH and parts of the Northern Phyllite Zone, which are covered by the thick Permo-Carboniferous deposits of the Saar-Nahe Basin. Further local anomaly highs are found at the Frankenstein Complex and at the southeastern Palatinate, both of which can be explained by the presence of mafic 
rocks. The most pronounced gravity low is located in the granites/granodiorites area of the southern Odenwald and along the SW extension of the Flasergranitoid Zone.

A comparison of the residual Bouguer anomalies with the pole-reduced magnetic anomalies shows that there are partly strong correlations between these two potential fields, which is a prerequisite for the joint inversion. This is particularly evident in the Odenwald: positive correlation in the Frankenstein complex and the Böllstein Odenwald, negative correlation in the southern Odenwald. A negative correlation occurs furthermore in the northwestern MGCH and the Saxothuringian Zones, where gravity highs coincide with magnetic lows. In contrast, a clear relationship exists not everywhere in the inner part of the URG. The separation of the Flasergranitoid Zone and southern Granitoids is thus subject to larger uncertainties.

\subsection{Inverse Model}

Figs. 8 shows a comparison of the 3D basement forward model with the most probable model of the northern URG derived from the joint inversion of gravity and magnetic data. After the inversion, the interfaces are locally shifted by up to $10 \mathrm{~km}$. Particularly large changes occur at the boundary between MGCH and the Northern Phyllite Zone. The tectonic contact is located further north and appears more irregular than presumed. Note, however, that the very similar petrophysical properties of these two units (Tab. 4) make a separation with the inversion approach difficult. The associated uncertainties are emphasized by the reduced probability of the inversion result in this area (Figs. 8C \& F). Along Profile AA' (Figs. 8D \& 8E), the main features of the inverted model correspond broadly to the forward model. As in the map view, the reduced thickness of the Northern Phyllite Zone is apparent. The interfaces of the inverse model are in general irregularly shaped, which might be related to the random character of the Monte Carlo simulation. Again, the probability of inversion results reveals uncertainties of locally several kilometers at the unit boundaries.

The mean density and susceptibility distributions at the top of the basement are illustrated in Figs. 9A \& 9B. Local clusters of these properties are present within and across individual model units, indicating lithological variations type in the respective area. In the Odenwald, the inverted density directly corresponds with the mapped lithologies: high density for mafic rocks of the Frankenstein Complex, intermediate densities in the dioritic domains of the Flasergranitoid Zone and relatively low densities in the predominantly felsic areas of the southern Odenwald. In contrast, the susceptibility varies over more than four orders of magnitude in the study area, making correlation with the lithology more difficult. Particularly high values are found along the Frankenstein Complex and the Southwestern Magnetic Body, but also in the southern 
554 Odenwald. Another highly magnetized body is located at the northern margin of the MGCH, 555 which is also characterized by a relatively high density, indicating the presence of intermediate 556 to mafic magmatic rocks. The metasedimentary units, in particular the Rhenohercynian, the 557 Northern Phyllite and the Saxothuringian Zone, generally exhibit very low susceptibilities. Fig. $5589 \mathrm{C} \& 9 \mathrm{D}$ show the standard deviations of the inverted density and susceptibility calculated for 559 each cell of the model. Increased values occur at the model unit boundaries and in the areas 560 of high susceptibility, but are still very small relative to the mean. Consequently, a high level of 561 confidence in the inverted petrophysical models can be assumed.

562 A comparison of the initial, optimized and inverted model parameters is given in Tab. 4 for the 563 basement units. For the rock density, only small differences can be observed between the 564 values derived from the petrophysical data and the final values. Thus, these existing databases 565 provide already a representative image of the density distribution, at least in the $\mathrm{MGCH}$. By 566 contrast, the magnetic susceptibility shows significantly stronger differences between initial 567 and inverted parameters, e.g., in the Böllstein Odenwald or the Southern Plutons. These, 568 however, are still within the natural variations of the susceptibility, which were measured on 569 the outcrop samples (Tab. 2). 

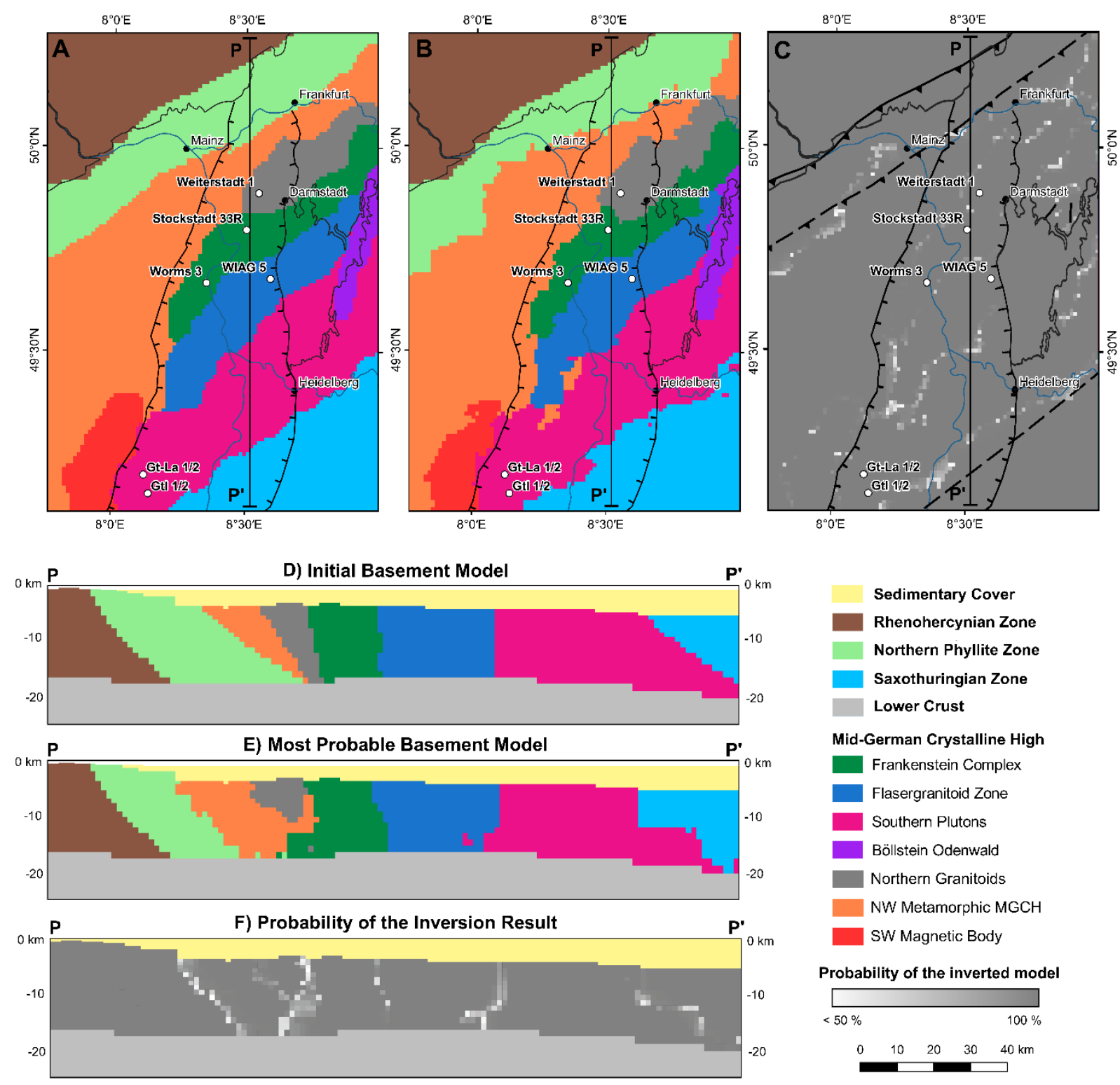

Probability of the inverted model

571 Figure 8: Summary of the joint inversion results: (A) forward model at the top basement; (B) most probable model 572 after inversion at the top basement; (C) probability of the inverted model at the top basement; (D) forward model 573 along profile PP'; (E) most probable model after inversion along profile PP'; (F) probability of the inverted model 574 along profile PP'. 

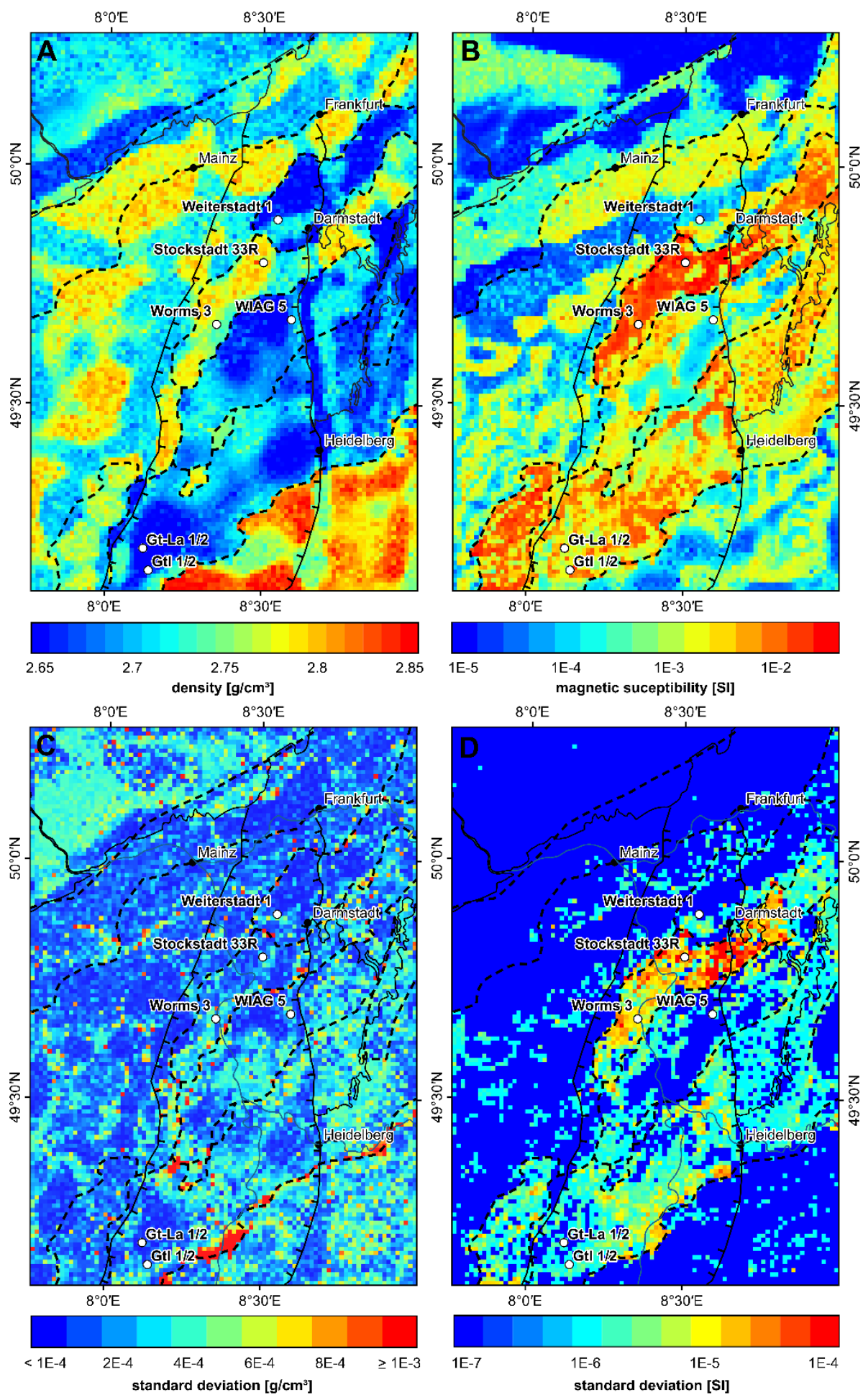

577 Figure 9: Overview of the inverted petrophysical properties: (A) mean density at the top of basement, (B) mean 578 susceptibility; (C) \& (D) standard deviation of the inverted properties for each cell. The dashed lines represent the 579 interfaces of the inverted model units. 
581 Table 4: Summary of petrophysical model parameters. Magnetic properties were only considered in the basement 582 model. The properties of the basement units were derived from the available petrophysical databases (initial values) 583 and then optimized (optimized values; see Section 3.1.3 for more details). During the joint inversion, the anomaly

584 misfit is further reduced by adjusting the property distribution.

585

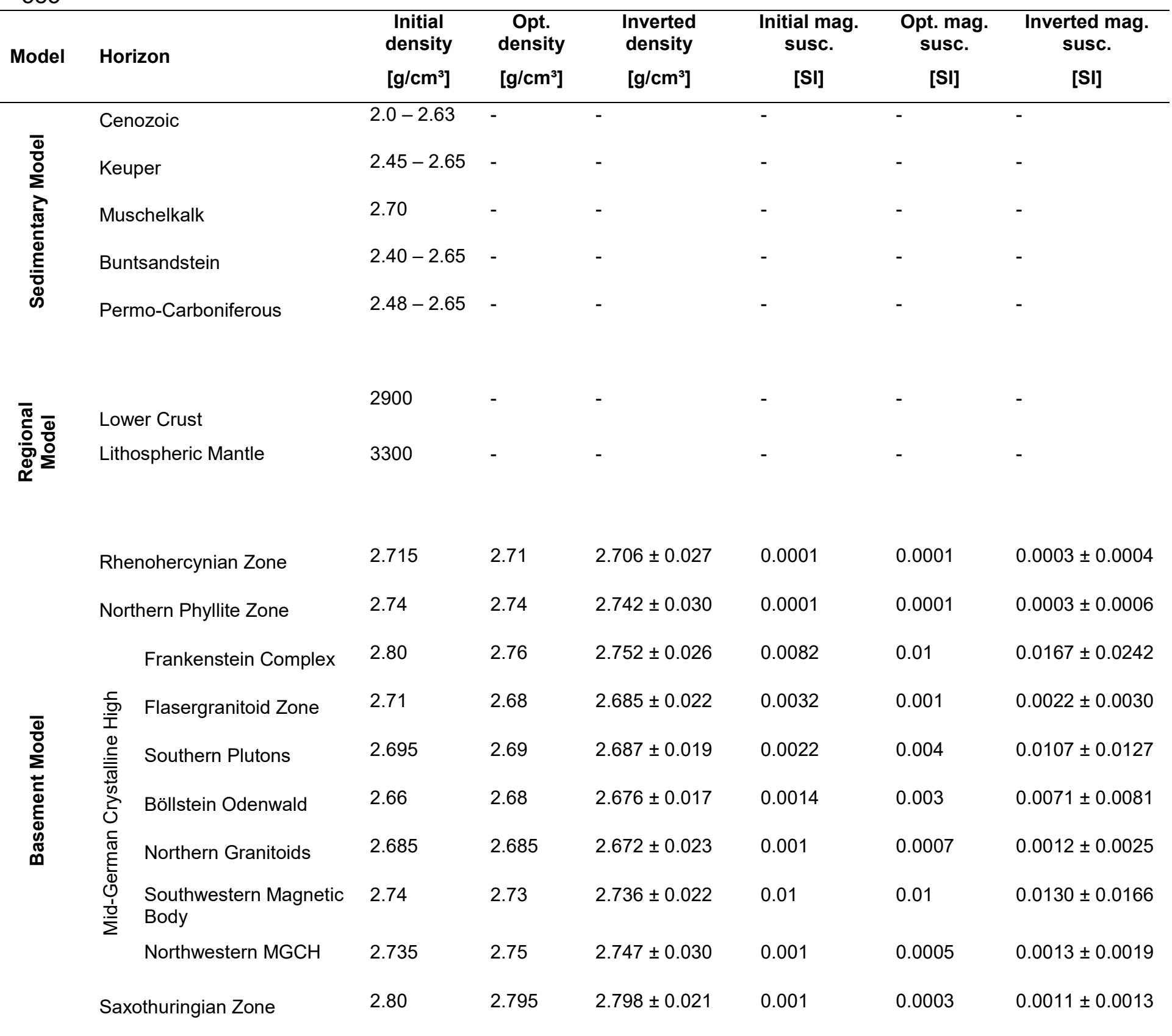



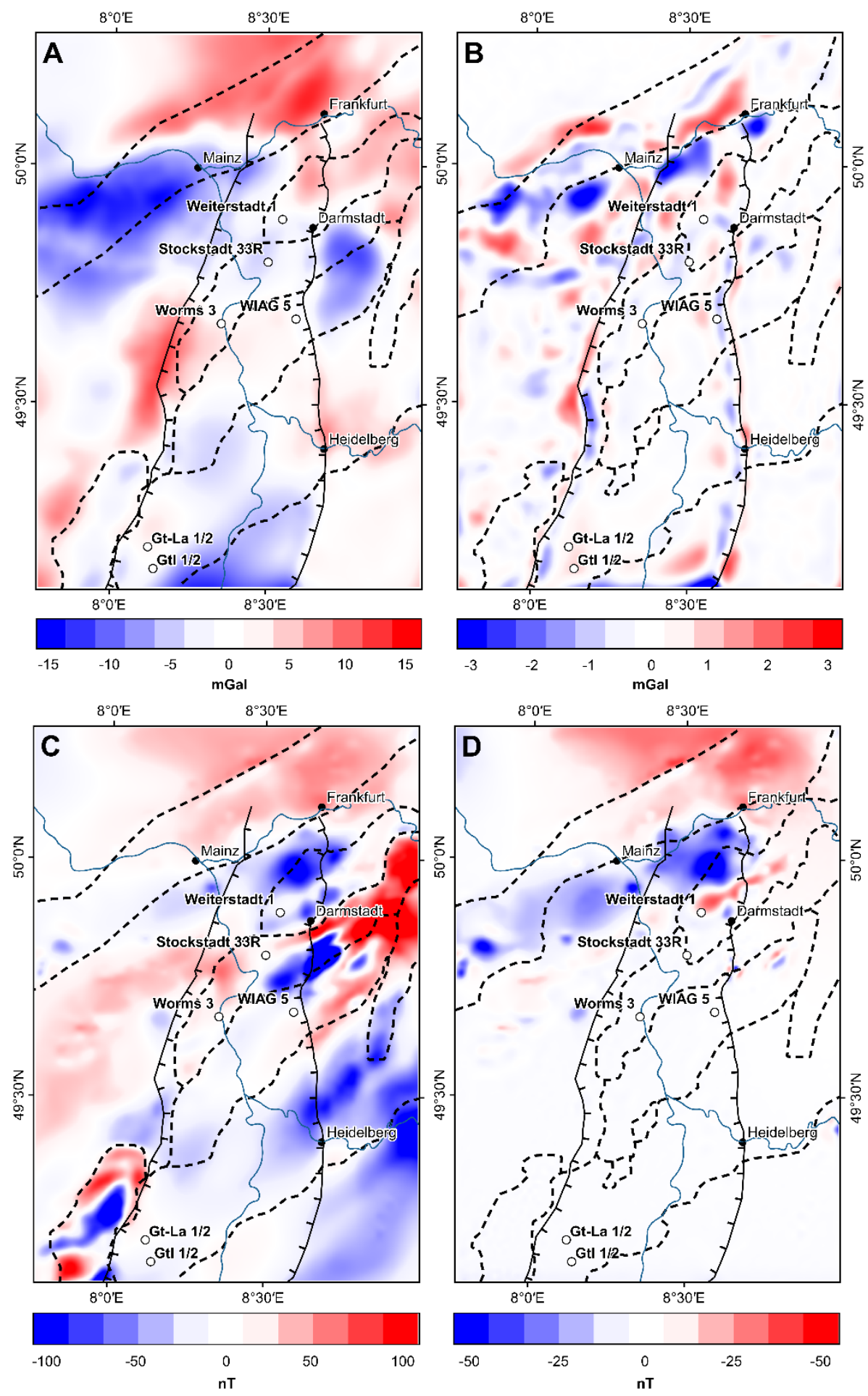

592 Fig. 10: Misfit between modelled and observed anomalies: (A) misfit of the forward modelled residual Bouguer anomalies; (B) misfit of the inverted residual Bouguer anomalies; (C) misfit of the forward calculated magnetic anomalies; (D) misfit of the inverted magnetic anomalies. The dashed lines represent the interfaces of the initial (A \& C) respectively inverted model units $(B \& D)$.

Fig. 10 shows the misfits between the observed and forward modelled respectively inverted potential fields. The forward model is able to describe the main features of the Bouguer 
anomalies and parts of the magnetic anomalies, but the RMS misfit is still relatively high with $5.3 \mathrm{mGal}$ and $42.1 \mathrm{nT}$. Particularly large differences can be observed at the transition from the MGCH to the Northern Phyllite Zone. Moreover, the magnitude of the magnetic anomalies is usually underestimated. After the inversion, the RMS misfit is with $0.6 \mathrm{mGal}$ and $11.0 \mathrm{nT}$ reduced by $90 \%$ and $75 \%$, respectively. The largest deviations of the Bouguer anomalies are still found in the northwestern MGCH and the Northern Phyllite Zone as well as along the main border faults, but the differences between the observation and the model are now relatively small ( $\pm 4 \mathrm{mGal}$ ). In addition, the modelled magnetic anomalies are significantly improved, especially in the inner part of the URG. Larger differences still exist in the north, possibly due to the influence of the volcanic rocks of the Vogelsberg and Permo-Carboniferous, which were not considered during inversion.

\section{Discussion}

\subsection{Uncertainties of Applied Methods}

611 A detailed 3D basement model of the northern URG was developed by integrating available structural information as well as gravity and magnetic data. Especially the stripping of the sedimentary and regional gravity field (Fig. 7) was helpful as the residual Bouguer anomalies provide key insights on the composition of the crystalline upper crust. However, it should be noted that this approach is affected by various uncertainties. First of all, the horizon depths in the sediment model are subject to errors that have an impact on the calculated gravity field of several $\mathrm{mGal}$. Likewise, the defined density distribution at depth is uncertain since it is only supported by a few data points. A laterally homogeneous density gradient was assumed, which may not reflect the actual variations within the sediments. Particularly large uncertainties exist in connection with the Permo-Carboniferous volcanic formations. They are typically characterized by a variable thickness and composition, with the density ranging from 2.6 to more than $3.0 \mathrm{~g} / \mathrm{cm}^{3}$, thus causing the gravity effect to vary considerably. In the Mainz Basin, these volcanic horizons have a significant but hardly quantifiable impact on the gravity anomalies, which makes the separation of the underlying $\mathrm{MGCH}$ and the Northern Phyllite Zone challenging.

626 For the modelling of the magnetic anomalies, the susceptibility of all post-Variscan deposits was set to 0 [SI]. This assumption is roughly valid for the clastic and carbonate sediments, but Permo-Carboniferous and Cenozoic volcanic deposits show in general higher susceptibilities.

629 They might be sources of stronger magnetic anomalies in the Saar-Nahe Basin, on the 630 Sprendlinger Horst and in the northernmost URG. Ignoring their effect leads most likely to the 631 increased anomaly misfits in these areas (Fig. 10) and can partly corrupt the inversion result. 
An improved sediment model including the volcanic intercalations and better knowledge about

633 the petrophysical properties would consequently result in a more accurate calculation of the

634 gravity and magnetic anomalies. This, however, would require an extension of the

635 petrophysical database and an in-depth analysis of the existing well logs.

636 Moreover, also the regional gravity model is affected by some uncertainty. On the one hand, 637 the seismic profiles and receiver function data on which the depth of the lower crust and the 638 Moho are based are very sparse. On the other hand, this data can be subject to errors of 639 several kilometers. This can easily lead to variations in the calculated gravity effect of up to 10 $640 \mathrm{mGal}$. But these uncertainties influence the inversion only to a limited extent because the 641 wavelength is generally very long.

642 The basement model resulting from the joint inversion is able to describe the gravity and 643 magnetic anomalies very well (Figs. 10B \& 10D). It can therefore be assumed, that the final 644 density and susceptibility distributions are realistic representations of the crystalline basement. 645 Nevertheless, due to the random character of the Monte Carlo simulation also geologically 646 implausible features might be generated, making a thorough plausibility check of the inversion 647 result necessary. Furthermore, the inversion result depends to a large extent on the inversion 648 parameters and the starting model, but the general agreement with the crystalline outcrops at 649 the graben shoulders and the wells in the northern URG shows that the selected initial 650 conditions are reasonable. Indications of model uncertainties are provided by the probabilities 651 of the inverted 3D structures (Figs. 8C \& 8F).

\subsection{Basement Structure and Composition}

653 The petrophysical analysis revealed that the rock density and magnetic susceptibility are 654 strongly depending on the lithology (Tab. 2). Conversely, information on the distribution of the 655 main lithologies in the crystalline basement of the northern URG can be deduced from the 656 inverted parameter models (Fig. 9). Based on the outcrops at the graben margins, the deep 657 crystalline wells in the URG, and the density and susceptibility models, an interpretive geologic 658 map of the basement beneath the sedimentary cover was generated. (Fig. 11). Areas with 659 comparatively low magnetic susceptibility $\left(<10^{-3}[S I]\right)$ are interpreted as being predominantly metamorphic. This assumption can be confirmed in the Northern Phyllite Zone, the 661 Rhenohercynian Zone, and the Saxothuringian Zone, whose composition is relatively well 662 known from outcrops. It is also suggested that metamorphic rocks are dominant in the 663 northwestern $\mathrm{MGCH}$, which is supported by exposed early Paleozoic metasediments in the 664 Palatinate and the petrophysical similarities to the Saxothuringian and Northern Phyllite Zone. 665 The transition between the metamorphic MGCH to the Northern Phyllite Zone is not marked 
by a sharp discontinuity in the residual gravity signal, indicating major lithological parallels and

667 a paired evolution of these units in a volcanic arc respectively fore-arc setting (Krohe, 1991).

668 Large parts of the northern URG basement and the area east of it are presumably dominated 669 by plutonic rocks given the high magnetic susceptibility. The distinction between different

670

671

672

673

674

675

676

677

678

679

680

681

682

683

684

685

686

687

688

689

690

691

692

693

694

695

696

697

698 magmatic rocks is primarily based on the rock density (Tab. 2). According to this, granites and granodiorites occur mainly in the southwestern extension of the Flasergranitoid Zone and in the southern Bergsträßer Odenwald. The boundary between these two units cannot be clearly traced in the density model, but the Flasergranitoid Zone is generally characterized by lower susceptibility or, alternatively, increased remanent magnetization. Mafic rocks are concentrated in a NNE-SSW trending band that includes the Southwestern Magnetic Body and the Frankenstein Complex. Intermediate rocks may be present along the northern margin of the MGCH, supported by the two wells Neuhof 1 and 2 encountering diorite.

The interpretation covers only the larger geological bodies, small-scale lithological variations cannot be resolved with the applied method so far. Example for this are the narrow amphibolitegneiss complexes, the so-called Schieferzüge, in the Bergsträßer Odenwald, which are most likely continuous towards the southwest. Their location in the northern URG can only be estimated by assuming a constant strike direction. Furthermore, the natural variations of the petrophysical parameters as well as the partial overlap of the parameter distributions of different rock types imply considerable uncertainties in the separation of individual lithologies. Also, in addition to the main rock type, density and magnetic susceptibility depend on several aspects such as fracture porosity, hydrothermal alteration or mineral alteration (Airo, 2002; Ladygin et al., 2000; Ündül, 2016), which cannot be quantified here in detail due to the lack of comprehensive well data.

Despite the significant uncertainties, the presented investigations provide an important basis for geothermal potential assessments in the northern URG. As mentioned above, especially thermal but also hydraulic parameters are strongly affected by the lithology (Stober and Bucher, 2007). Granitoids, which are the crystalline rocks with the most favorable properties for geothermal exploitation, represent more than $50 \%$ of the basement in the northern URG. In comparison, the less suitable mafic and metamorphic rocks occupy a rather subordinate area. Additionally, Weinert et al. (2020a) found a direct relationship between bulk density and thermal conductivity for the rock samples of the $\mathrm{MGCH}$. The petrophysical models can therefore be used to infer the spatial distribution of thermal properties in the basement, allowing again more realistic potential estimates and heat flow simulations. 

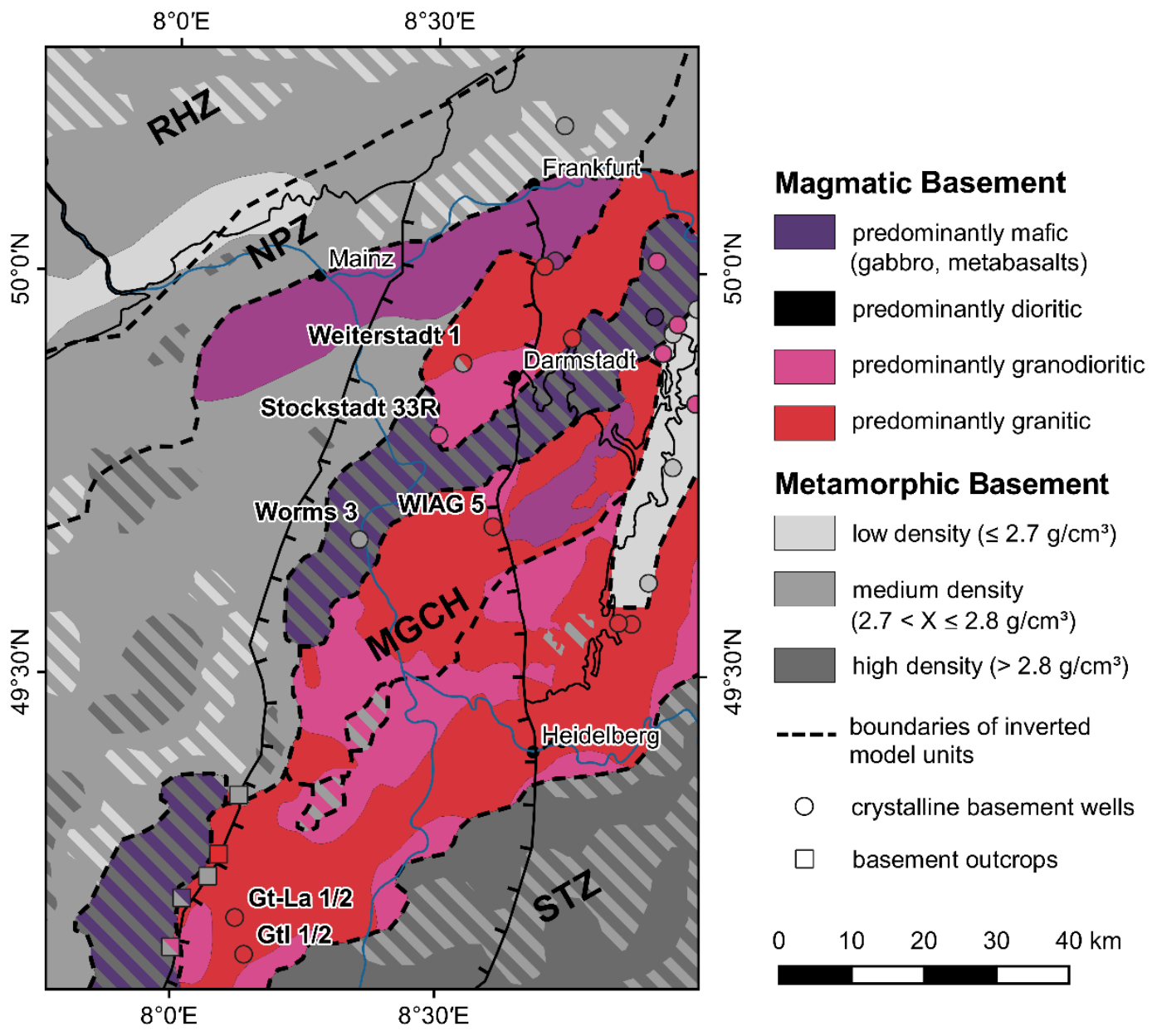

Figure 11: Interpretative map of the lithologies at the top basement based on the results of the joint gravity and magnetic inversion. Available crystalline basement wells and outcrops at the graben shoulders are largely consistent with the interpretation. RHZ = Rhenohercynian Zone, NPZ = Northern Phyllite Zone, $\mathrm{MGCH}=$ MidGerman Crystalline High, STZ = Saxothuringian Zone, URG = Upper Rhine Graben .

\subsection{Geodynamic Interpretation}

The $\mathrm{MGCH}$ is traditionally regarded as a volcanic arc or active continental margin, which was formed in the Late Devonian and Carboniferous by the southward subduction of the Rheic and

707 Rhenohercynian Oceans and later continental collision (Franke, 2000; Kroner et al., 2008; Zeh and Gerdes, 2010). Due to contrasting geodynamic conditions along the strike direction, a zone of variable composition and structure has formed. Especially on the opposite sides of the

710 URG, there are significant differences, mainly due to oblique convergence (Flöttmann and 711 Oncken, 1992; Oncken, 1997). Accordingly, the MGCH is probably dominated by a 712 metamorphic basement in the west, which can be interpreted as the relic of a Paleozoic fore713 arc. East of the URG, the convergence rates during the main orogeny phase were much higher, 714 therefore the fore-arc is not preserved in this area. Instead, subduction-related plutons and 715 metamorphic rocks with pressure-dominated overprint are present here. 
The Frankenstein Complex and Southwestern Magnetic Body are likely the remains of a volcanic island arc (e.g. Altherr et al., 1999), which was formed in an early phase of the marine basin closure. Whereas the basement is largely exposed in the Odenwald, it is covered by Carboniferous to Triassic (meta-)sediments in the Palatinate. It appears that these two units are separated by a 15 to $20 \mathrm{~km}$ sinistral offset near the western graben boundary fault. This observation might be attributed to the sinistral strike-slip movements in the URG, which are particularly evident in the central and southern rift valley. Alternatively, this setting might still represent the primary geometry of the Variscan orogen with a changing trend from NE-SW in the Odenwald to NNE-SSW in the Palatinate and Vosges.

\section{Conclusions and Outlook}

All publicly available structural and petrophysical data on the crystalline basement in the northern URG were compiled into one comprehensive model. By integrating gravity and magnetic data, a detailed geological 3D model of the region was developed. From the investigations described above, the following conclusions can be drawn:

- Residual Bouguer and magnetic anomalies exhibit NE-SW oriented features that depict the main Variscan basement structures. The metamorphic units are usually recognized by gravity highs and magnetic lows, whereas the magmatic complexes are often associated with magnetic highs and varying gravity anomalies.

- Joint inversion modelling allowed to obtain a density and susceptibility model of the crystalline basement in the northern URG region which provides a good match with the observed gravity and magnetic data

- The petrophysical analysis demonstrated that the main rock types are characterized by specific properties. The inversion results can therefore be used to draw up an interpretative map of the basement lithology in the northern URG, which is also consistent with outcrops and wells.

- Major parts of the northern URG basement are dominated by granitoid intrusions that offer suitable properties for deep geothermal utilization. Metamorphic and mafic rocks are concentrated in a relatively narrow band and along the western graben border. However, it must be mentioned that this interpretation remains speculative due to the non-uniqueness of potential fields studies. Besides, only larger connected bodies can be resolved; investigation of small-scale lithologic variations is not possible based on the currently available data.

In the future studies, efforts will be focused on using the developed 3D model to perform a 
distribution of thermal properties can be derived from the inverted density model. Furthermore, comprehensive structural geological information will be integrated, mainly from the Odenwald, to assess the hydraulic properties of the basement.

To reduce the uncertainties related to the Permo-Carboniferous and Cenozoic volcanics, a detailed analysis of well data from the northernmost URG, the Saar-Nahe Basin and the Sprendlinger Horst is necessary. In particular, the incorporation of all existing well logs would improve the understanding of the location, thickness and properties of these horizons. In addition, the joint inversion of gravitational and magnetic data is also promising on a smaller scale, since a higher resolution of the discretized model would allow to map the properties of large fault zones, which represent the main target for geothermal projects in the URG. For this purpose, the integration of existing 3D seismic data sets, that allow a precise modelling of the geological structures, seems promising. This would minimize the uncertainties of the forward model considerably and the inversion could provide more reliable results.

\section{Acknowledgements}

We thank all researchers and involved institutions (TUDa, GFZ, HLNUG, LGRB-BW, LGB-RP) of the Hessen 3D (1.0 and 2.0) and GeORG projects, whose activities were essential for this study. We are furthermore grateful that the Institut für Steinkonservierung Mainz e.V. provided the rock samples of the URG region for our petrophysical investigations. We thank Prof. Dr. Eva Schill for the helpful discussions on the analysis and interpretation of the geophysical data. Additionally, we thank Dr. Jens Grimmer and one anonymous reviewer for their critical but constructive reviews and comments which helped to improve the manuscript considerably.

\section{Funding}

This study was funded by the Interreg NWE Program through the Roll-out of Deep Geothermal Energy in North-West Europe (DGE-ROLLOUT) Project (www.nweurope.eu/DGE-Rollout). The Interreg NWE Program is part of the European Cohesion Policy and is financed by the European Regional Development Fund (ERDF).

\section{Data Availability Statement}

Datasets containing petrophysical properties of the crystalline basement in the URG region including density and magnetic susceptibility measurements can be found at https://doi.org/10.5194/essd-12-2485-2020 (Bär et al., 2020), https://doi.org/10.25534/tudatalib-278 (Weinert et al., 2020b) and https://doi.org/10.48328/tudatalib-393 (Frey et al., 2020). Gravity and magnetic data can be 
requested individually from the Leibniz Institute for Applied Geophysics (LIAG), the Hessian Administration for Soil Management and Geoinformation (HVBG) and the State Agency for Surveying and Geo Base Information Rhineland-Palatinate (LVermGeo). Finally, the 3D model of the northern URG crystalline basement is publicly available at https://doi.org/10.48328/tudatalib-417.2 (Frey et al., 2021).

\section{References}

Agemar, T., Schellschmidt, R., Schulz, R., 2012. Subsurface Temperature Distribution of Germany. Geothermics 44, 65-77. https://doi.org/10.1016/j.geothermics.2012.07.002. Airo, M.-L., 2002. Aeromagnetic And Aeroradiometric Response To Hydrothermal Alteration. Surveys in Geophysics 23, 273-302. https://doi.org/10.1023/A:1015556614694.

Altenberger, U., Besch, T., 1993. The Bllstein Odenwald: evidence for pre- to early Variscan plate convergence in the Central European variscides. International Journal of Earth Sciences 82 (3), 475-488. https://doi.org/10.1007/BF00212411.

Altherr, R., Henes-Klaiber, U., Hegner, E., Satir, M., Langer, C., 1999. Plutonism in the Variscan Odenwald (Germany): from subduction to collision. International Journal of Earth Sciences 88, 422-443. https://doi.org/10.1007/s005310050276.

Anderle, H.-J., Franke, W., Schwab, M., 1995. III.C.1 Stratigraphy, in: Dallmeyer, R.D., Franke, W., Weber, K. (Eds.), Pre-Permian Geology of Central and Eastern Europe. Springer Berlin Heidelberg, Berlin, Heidelberg, pp. 99-107.

Anthes, G., Reischmann, T., 1997. New 207Pb/206Pb single zircon evaporation ages from the central part of the Mid German Crystalline Rise. Terra Nostra 97 (5), 10. https://doi.org/10.1016/j.jseaes.2007.04.004.

Aretz, A., Bär, K., Götz, A.E., Sass, I., 2016. Outcrop analogue study of Permocarboniferous geothermal sandstone reservoir formations (northern Upper Rhine Graben, Germany): impact of mineral content, depositional environment and diagenesis on petrophysical properties. International Journal of Earth Sciences 105 (5), 1431-1452. https://doi.org/10.1007/s00531-015-1263-2.

Arndt, D., 2012. Geologische Strukturmodellierung von Hessen zur Bestimmung von Geopotenzialen. Dissertation, Technical University of Darmstadt, $116 \mathrm{pp}$.

Bächler, D., Kohl, T., Rybach, L., 2003. Impact of graben-parallel faults on hydrothermal convection-Rhine Graben case study. Physics and Chemistry of the Earth, Parts A/B/C 28, 431-441. https://doi.org/10.1016/S1474-7065(03)00063-9.

Backhaus, E., 1974. Limnische und fluviatile Sedimentation im südwestdeutschen Buntsandstein. International Journal of Earth Sciences 63 (3), 925-942. https://doi.org/10.1007/BF01821318.

Backhaus, E., 1975. Der Buntsandstein im Odenwald, in: Amstutz, G.C., Meisl, S., Nickel, E. (Eds.), Mineralien und Gesteine im Odenwald. Heidelberg, pp. 299-320.

Backhaus, E., Heim, D., 1995. Die fluvio-lakustrine Fazies des Übergangsbereichs Plattensandstein/Rötquarzit (Oberer Buntsandstein) im mittleren Odenwald unter besonderer Berücksichtigung der Violetten Zone. Geol. Jb. Hessen 123, 49-68.

Backhaus, E., Schwarz, S., 2003. Ein Sammelprofil des Buntsandsteins und Zechsteins im mittleren Odenwald anhand von Bohrungen und Gamma-Logs. Geol. Jb. Hessen 130, 91-107. 
Baillieux, P., Schill, E., Edel, J.-B., Mauri, G., 2013. Localization of temperature anomalies in the Upper Rhine Graben: insights from geophysics and neotectonic activity. International Geology Review 55 (14), 1744-1762. https://doi.org/10.1080/00206814.2013.794914.

Bär, K.M., 2012. Untersuchung der tiefengeothermischen Potenziale von Hessen. Dissertation, Technical University of Darmstadt, $268 \mathrm{pp}$.

Bär, K., Hintze, M., Weinert, S., Sippel, J., Freymark, J., Scheck-Wenderoth, M., Sass, I., 2016. Das Verbundprojekt Hessen 3D 2.0. Geothermische Energie 3 (85), 24-25.

Bär, K., Reinsch, T., Bott, J., 2020. The PetroPhysical Property Database $\left(\mathrm{P}^{3}\right)$ - a global compilation of lab-measured rock properties. Earth Syst. Sci. Data 12 (4), 2485-2515. https://doi.org/10.5194/essd-12-2485-2020.

Bär, K., Homuth, B., Stiller, M., Weinert, S., Bott, J., Oncken, O., Franke, W., Henke, A., 2021, in prep. New Interpretation of a reprocessed Crustal Scale Seismic Profile across the Mid German Crystalline High and the Northern Upper Rhine Graben, Germany. In preparation for Geochemistry, Geophysics, Geosystems, AGU Advancing Earth and Space Science Journal.

Behr, H.-J., Engel, W., Franke, W., Giese, P., Weber, K., 1984. The Variscan Belt in Central Europe: Main structures, geodynamic implications, open questions. Tectonophysics 109 (1-2), 15-40. https://doi.org/10.1016/0040-1951(84)90168-9.

Behr, H.J., Heinrichs, T., 1987. Geological interpretation of DEKORP 2-S: A deep seismic reflection profile across the Saxothuringian and possible implications for the Late Variscan structural evolution of Central Europe. Tectonophysics 142 (2-4), 173-202. https://doi.org/10.1016/0040-1951(87)90122-3.

Behrmann, J.H., Hermann, O., Horstmann, M., Tanner, D.C., Bertrand, G., 2003. Anatomy and kinematics of oblique continental rifting revealed: A three-dimensional case study of the southeast Upper Rhine graben (Germany). Bulletin 87 (7), 1105-1121. https://doi.org/10.1306/02180300153.

Böcker, J., 2015. Petroleum system and thermal history of the Upper Rhine Graben Implications from organic geochemical analyses, oil-source rock correlations and numerical modelling. Dissertation, RWTH Aachen, 154 pp.

Boigk, H., Schöneich, H., 1974. The Rhinegraben: geologic history and neotectonic activity Perm, Trias und älterer Jura im Bereich der südlichen Mittelmeer-Mjösen-Zone und des Rheingrabens, in: Illies, J.H., Fuchs, K. (Eds.), Approaches to Taphrogenesis. Schweizerbart, Stuttgart, pp. 60-72.

Boigk, H., 1981. Erdöl und Erdölgas in der Bundesrepublik Deutschland. Schweizerbart, Stuttgart, $330 \mathrm{pp}$.

Bosch, M., McGaughey, J., 2001. Joint inversion of gravity and magnetic data under lithologic constraints. The Leading Edge 20 (8), 877-881. https://doi.org/10.1190/1.1487299.

Bosch, M., Meza, R., Jiménez, R., Hönig, A., 2006. Joint gravity and magnetic inversion in 3D using Monte Carlo methods. GEOPHYSICS 71 (4), G153-G156. https://doi.org/10.1190/1.2209952.

Brun, J.P., Gutscher, M.-A., teams, 1992. Deep crustal structure of the Rhine Graben from dekorp-ecors seismic reflection data: A summary. Tectonophysics 208 (1-3), 139-147. https://doi.org/10.1016/0040-1951(92)90340-C.

Buchmann, T.J., Connolly, P.T., 2007. Contemporary kinematics of the Upper Rhine Graben: A 3D finite element approach. Global and Planetary Change 58, 287-309. https://doi.org/10.1016/j.gloplacha.2007.02.012. 
Buchner, F., 1981. Rhinegraben: Horizontal stylolites indicating stress regimes of earlier stages of rifting. Tectonophysics 73 (1-3), 113-118. https://doi.org/10.1016/00401951(81)90178-5.

Calcagno, P., Chilès, J.P., Courrioux, G., Guillen, A., 2008. Geological modelling from field data and geological knowledge, Part I - Modelling method coupling 3D potential-field interpolation and geological rules. Physics of the Earth and Planetary Interiors 171 (1-4), 147-157. https://doi.org/10.1016/j.pepi.2008.06.013.

Crowley, Q.G., Floyd, P.A., Winchester, J.A., Franke, W., Holland, J.G., 2000. Early Terrane Assemblage. Terra Nova 12 (4), 171-180. https://doi.org/10.1046/j.13653121.2000.00290.x.

Dachroth, W., 1988. Genese des linksrheinischen Buntsandsteins und Beziehungen zwischen Ablagerungsbedingungen und Stratigraphie. Jahresberichte und Mitteilungen des Oberrheinischen Geologischen Vereins 70, 267-333. https://doi.org/10.1127/jmogv/70/1988/267.

Dallmeyer, R.D., Franke, W., Weber, K. (Eds.), 1995. Pre-Permian Geology of Central and Eastern Europe. Springer Berlin Heidelberg, Berlin, Heidelberg, 593 pp.

Dezayes, C., Lerouge, C., Innocent, C., Lach, P., 2021. Structural control on fluid circulation in a graben system: Constraints from the Saint Pierre Bois quarry (Vosges, France). Journal of Structural Geology 146, 104323. https://doi.org/10.1016/j.jsg.2021.104323.

Dèzes, P., Schmid, S.M., Ziegler, P.A., 2004. Evolution of the European Cenozoic Rift System: interaction of the Alpine and Pyrenean orogens with their foreland lithosphere. Tectonophysics 389 (1-2), 1-33. https://doi.org/10.1016/j.tecto.2004.06.011.

Doebl, F., 1967. The Tertiary and Pleistocene sediments of the northern and central part of the Upper Rhinegraben. Abhandlungen des Geologischen Landesamtes BadenWürttemberg 6, 48-54.

Doebl, F., Olbrecht, W., 1974. An isobath map of the Tertiary base in the Rhinegraben, in: Illies, J.H., Fuchs, K. (Eds.), Approaches to Taphrogenesis. Schweizerbart, Stuttgart, pp. 71-72.

Edel, J.B., Fluck, P., 1989. The upper Rhenish Shield basement (Vosges, Upper Rhinegraben and Schwarzwald): Main structural features deduced from magnetic, gravimetric and geological data. Tectonophysics 169 (4), 303-316. https://doi.org/10.1016/0040-1951(89)90093-0.

Edel, J.B., Weber, K., 1995. Cadomian terranes, wrench faulting and thrusting in the central Europe Variscides: geophysical and geological evidence. International Journal of Earth Sciences 84. https://doi.org/10.1007/BF00260450.

Edel, J.-B., Schulmann, K., Rotstein, Y., 2007. The Variscan tectonic inheritance of the Upper Rhine Graben: evidence of reactivations in the Lias, Late Eocene-Oligocene up to the recent. International Journal of Earth Sciences 96, 305-325. https://doi.org/10.1007/s00531-006-0092-8.

Edel, J., Schulmann, K., 2009. Geophysical constraints and model of the "Saxothuringian and Rhenohercynian subductions - magmatic arc system" in NE France and SW Germany. Bulletin De La Societe Geologique De France - BULL SOC GEOL FR 180, 545-558. https://doi.org/10.2113/gssgfbull.180.6.545.

Edel, J.B., Maurer, V., Dalmais, E., Genter, A., Richard, A., Letourneau, O., Hehn, R., 2018. Structure and nature of the Palaeozoic basement based on magnetic, gravimetric and seismic investigations in the central Upper Rhinegraben. Geothermal Energy 6 (1), 13. https://doi.org/10.1186/s40517-018-0099-y. 
Feist-Burkhardt, S., Götz, A., Szulc, J., Borkhataria, R., Geluk, M., Haas, J., Hornung, J., Jordan, P., Kempf, O., Jozef, M., Nawrocki, J., Reinhardt, L., Ricken, W., Röhling, H.-G., Rüffer, T., Török, Á., Zuehlke, R., 2008. Triassic, in: McCann, T. (Ed.), The Geology of Central Europe: Volume 2: Mesozoic and Cenozoic. Geological Society of London, London, pp. 749-821.

Flöttmann, T., Oncken, O., 1992. Contraints on the evolution of the Mid German Crystalline Rise - a study of outcrops west of the river Rhine. Geologische Rundschau 82 (2), 515543.

Franke, W., 2000. The mid-European segment of the Variscides: tectonostratigraphic units, terrane boundaries and plate tectonic evolution. Geological Society, London, Special Publications 179, 35-61. https://doi.org/10.1144/GSL.SP.2000.179.01.05.

Franke, W., Cocks, L.R.M., Torsvik, T.H., 2017. The Palaeozoic Variscan oceans revisited. Gondwana Research 48, 257-284. https://doi.org/10.1016/i.gr.2017.03.005.

Frenzel, G., 1971. Die Mineralparagenese der Albersweiler Lamprophyre. Neues J. Mineral. Abh. 115, 164-191.

Frey, M., Bär, K., Sass, I., 2020. Database of the Magnetic Susceptibility of the Mid-German Crystalline High. Technical University of Darmstadt. TUdatalib. https://doi.org/10.48328/tudatalib-393.

Frey, M., Ebbing, J., 2020. The deep geothermal potential of the radiogenic Løvstakken Granite in western Norway. NJG. https://doi.org/10.17850/njg100-1-4.

Freymark, J., Sippel, J., Scheck-Wenderoth, M., Baer, K., Stiller, M., Kracht, M., Fritsche, J.G., 2015. Heterogeneous Crystalline Crust Controls the Shallow Thermal Field - A Case Study of Hessen (Germany). Energy Procedia 76, 331-340. https://doi.org/10.1016/i.egypro.2015.07.837.

Freymark, J., Sippel, J., Scheck-Wenderoth, M., Bär, K., Stiller, M., Fritsche, J.-G., Kracht, M., 2017. The deep thermal field of the Upper Rhine Graben. Tectonophysics 694, 114129. https://doi.org/10.1016/i.tecto.2016.11.013.

Freymark, J., Bott, J., Scheck-Wenderoth, M., Bär, K., Stiller, M., Fritsche, J.-G., Kracht, M., Gomez Dacal, M.L., 2020. 3D-URG: 3D gravity constrained structural model of the Upper Rhine Graben. GFZ Data Services. https://doi.org/10.5880/GFZ.4.5.2020.004.

Gabriel, G., Vogel, D., Scheibe, R., Lindner, H., Pucher, R., Wonik, T., Krawczyk, C.M., 2011. Anomalies of the Earth's total magnetic field in Germany - the first complete homogenous data set reveals new opportunities for multiscale geoscientific studies. Geophys J Int 184 (3), 1113-1118. https://doi.org/10.1111/j.1365-246X.2010.04924.x.

Gallardo, L.A., Thebaud, N., 2012. New insights into Archean granite-greenstone architecture through joint gravity and magnetic inversion. Geology 40 (3), 215-218. https://doi.org/10.1130/G32817.1.

Geyer, O.F., Gwinner, M.P., Simon, T., 2011. Geologie von Baden-Württemberg, 5th ed. Schweizerbart, Stuttgart, $627 \mathrm{pp}$.

Giese, P., 1995. Main Features of Geophysical Structures in Central Europe, in: Dallmeyer, R.D., Franke, W., Weber, K. (Eds.), Pre-Permian Geology of Central and Eastern Europe. Springer Berlin Heidelberg, Berlin, Heidelberg, pp. 7-25.

Grimmer, J.C., Ritter, J.R.R., Eisbacher, G.H., Fielitz, W., 2017. The Late Variscan control on the location and asymmetry of the Upper Rhine Graben. International Journal of Earth Sciences 106 (3), 827-853. https://doi.org/10.1007/s00531-016-1336-x.

Guillen, A., Calcagno, P., Courrioux, G., Joly, A., Ledru, P., 2008. Geological modelling from field data and geological knowledge, Part II, Modelling validation using gravity and magnetic data inversion. Physics of the Earth and Planetary Interiors 171 (1-4), 158-169. https://doi.org/10.1016/j.pepi.2008.06.014. 
Hammer, S., 1963. Deep Gravity Interpretation by Stripping. GEOPHYSICS 28 (3), 369-378. https://doi.org/10.1190/1.1439186.

Henk, A., 1992. Mächtigkeit und Alter der erodierten Sedimente im Saar-Nahe-Becken (SWDeutschland). International Journal of Earth Sciences 81 (2), 323-331. https://doi.org/10.1007/BF01828601.

Henk, A., 1993a. Late orogenic Basin evolution in the Variscan internides: the Saar-Nahe Basin, southwest Germany. Tectonophysics 223 (3-4), 273-290. https://doi.org/10.1016/0040-1951(93)90141-6.

Henk, A., 1993b. Subsidenz und tektonik des Saar-Nahe-Beckens (SW-Deutschland). International Journal of Earth Sciences 82 (1), 3-19. https://doi.org/10.1007/BF00563266.

Hertle, M., 2003. Numerische Simulation der geologischen Entwicklungsgeschichte des permokarbonen Saar-Nahe-Beckens. Dissertation, RWTH Aachen, 166 pp.

Hirschmann, G., 1995. IV.B Lithological Characteristics, in: Dallmeyer, R.D., Franke, W., Weber, K. (Eds.), Pre-Permian Geology of Central and Eastern Europe. Springer Berlin Heidelberg, Berlin, Heidelberg, pp. 155-163.

Homuth, B., Rümpker, G., Deckert, H., Kracht, M., 2014. Seismicity of the northern Upper Rhine Graben - Constraints on the present-day stress field from focal mechanisms. Tectonophysics 632, 8-20. https://doi.org/10.1016/..tecto.2014.05.037.

Illies, J.H., Greiner, G., 1979. Holocene Movements and State of Stress in the Rhinegraben Rift System 13, 349-359. https://doi.org/10.1016/B978-0-444-41783-1.50057-X.

Intrepid Geophysics, 2017. GeoModeller User Manual: Tutorial C (Forward \& Inverse Modelling of Potential Fields).

Jain, C., Vogt, C., Clauser, C., 2015. Maximum potential for geothermal power in Germany based on engineered geothermal systems. Geotherm Energy 3 (1). https://doi.org/10.1186/s40517-015-0033-5.

Jaupart, C., Mareschal, J.-C., larotsky, L., 2016. Radiogenic heat production in the continental crust. Lithos 262, 398-427. https://doi.org/10.1016/..lithos.2016.07.017.

Jodocy, M., Stober, I., 2010. Geologisch-geothermische Tiefenprofile für den südlichen Teil des Oberrheingrabens in Baden-Württemberg. Z. geol. Wiss. 38 (1), 3-25.

Kamm, J., Lundin, I.A., Bastani, M., Sadeghi, M., Pedersen, L.B., 2015. Joint inversion of gravity, magnetic, and petrophysical data - A case study from a gabbro intrusion in Boden, Sweden. GEOPHYSICS 80 (5), B131-B152. https://doi.org/10.1190/geo20140122.1.

Kemnitz, H., Romer, R.L., Oncken, O., 2002. Gondwana break-up and the northern margin of the Saxothuringian belt (Variscides of Central Europe). International Journal of Earth Sciences 91 (2), 246-259. https://doi.org/10.1007/s005310100209.

Kirsch, H., Kober, B., Lippolt, H.J., 1988. Age of intrusion and rapid cooling of the Frankenstein gabbro (Odenwald, SW-Germany) evidenced by40Ar/39Ar and singlezircon207Pb/206Pb measurements. International Journal of Earth Sciences 77 (3), 693711. https://doi.org/10.1007/BF01830178.

Klügel, T., 1997. Geometrie und Kinematik einer variszischen Plattengrenze: der Südrand des Rhenoherzynikums im Taunus. Hessisches Landesamt für Bodenforschung, 215 pp.

Kossmat, F., 1927. Gliederung des varistischen Gebirgsbaues: Abhandlungen Sächsischen Geologischen Landesamts, v. 1.

Kreuzer, H., Harre, W., 1975. K/Ar-Altersbestimmungen an Hornblenden und Biotiten des Kristallinen Odenwalds, in: Amstutz, G.C., Meisl, S., Nickel, E. (Eds.), Mineralien und Gesteine im Odenwald. Heidelberg, pp. 70-78. 
Krohe, A., 1991. Emplacement of synkinematic plutons in the Variscan Odenwald (Germany) controlled by transtensional tectonics. International Journal of Earth Sciences 80 (2), 391-409. https://doi.org/10.1007/BF01829373.

Krohe, A., 1992. Structural evolution of intermediate-crustal rocks in a strike-slip and extensional setting (Variscan Odenwald, SW Germany): differential upward transport of metamorphic complexes and changing deformation mechanisms. Tectonophysics 205 (4), 357-386. https://doi.org/10.1016/0040-1951(92)90443-A.

Krohe, A., Willner, A.P., 1995. IV.C.2 The Odenwald Crystalline Complex, in: Dallmeyer, R.D., Franke, W., Weber, K. (Eds.), Pre-Permian Geology of Central and Eastern Europe. Springer Berlin Heidelberg, Berlin, Heidelberg, pp. 182-185.

Kroner, U., Mansy, J.L., Mazur, S., Aleksandrowski, P., Hann, H.P., Huckriede, H., 2008. Variscan tectonics, in: McCann, T. (Ed.), The Geology of Central Europe: Volume 1: Precambrian and Palaeozoic. Geological Society of London, London, pp. 599-664.

Lachenbruch, A.H., 1970. Crustal temperature and heat production: Implications of the linear heat-flow relation. J. Geophys. Res. 75 (17), 3291-3300. https://doi.org/10.1029/JB075i017p03291.

Ladygin, V., Frolova, J., Rychagov, S., 2000. Formation of composition and petrophysical properties of hydrothermally altered rocks in geothermal reservoir. Proc. WGC, 26952699.

Lajaunie, C., Courrioux, G., Manuel, L., 1997. Foliation fields and 3D cartography in geology: Principles of a method based on potential interpolation. Math Geol 29 (4), 571-584. https://doi.org/10.1007/BF02775087.

Laue, S., Reischmann, T., Emmermann, K.H., 1990. Geochemical variation of granitoid rocks from the NW margin of the Rhinegraben. Ber Dsch Mineral Ges Eur J Mineral 2 (Beih 1), 156.

Laue, S., Reischmann, T., 1994. Petrographie und Geochemie variszischer Intrusiva der westlichen Rheingrabenschulter. Mitt Pollichia 81, 195-214.

Li, Y., Oldenburg, D.W., 1996. 3-D inversion of magnetic data. GEOPHYSICS 61 (2), 394408. https://doi.org/10.1190/1.1443968.

Li, Y., Oldenburg, D.W., 1998. 3-D inversion of gravity data. GEOPHYSICS 63 (1), 109-119. https://doi.org/10.1190/1.1444302.

Marell, D., 1989. Das Rotliegende zwischen Odenwald und Taunus. Geologische Abhandlungen Hessen, Wiesbaden.

Mareschal, J.-C., Jaupart, C., 2013. Radiogenic heat production, thermal regime and evolution of continental crust. Tectonophysics 609, 524-534. https://doi.org/10.1016/j.tecto.2012.12.001.

Martha, S.O., Zulauf, G., Dörr, W., Nesbor, H.-D., Petschick, R., Prinz-Grimm, P., Gerdes, A., 2014. The Saxothuringian-Rhenohercynian boundary underneath the Vogelsberg volcanic field: evidence from basement xenoliths and U-Pb zircon data of trachyte. zdgg 165, 373-394. https://doi.org/10.1127/1860-1804/2014/0079.

McCann, T. (Ed.), 2008a. The Geology of Central Europe: Volume 1: Precambrian and Palaeozoic. Geological Society of London, London, 748 pp.

McCann, T. (Ed.), 2008b. The Geology of Central Europe: Volume 2: Mesozoic and Cenozoic. Geological Society of London, London, 752 pp.

McCann, T., Skompski, S., Poty, E., Dusar, M., Vozarova, A., Schneider, J., Wetzel, A., Krainer, K., 2008. Carboniferous, in: McCann, T. (Ed.), The Geology of Central Europe: Volume 1: Precambrian and Palaeozoic. Geological Society of London, London, pp. 410530. 
1064

1065

1066

1067

1068

1069

1070

1071

1072

1073

1074

1075

1076

1077

1078

1079

1080

1081

1082

1083

1084

1085

1086

1087

1088

1089

1090

1091

1092

1093

1094

1095

1096

1097

1098

1099

1100

1101

1102

1103

1104

1105

1106

1107

1108

1109

1110

1111

Meier, L., Eisbacher, G.H., 1991. Crustal kinematics and deep structure of the northern Rhine Graben, Germany. Tectonics 10 (3), 621-630. https://doi.org/10.1029/91TC00142. Meissner, R., Bortfeld, R.K. (Eds.), 1990. DEKORP-Atlas: Results of Deutsches Kontinentales Reflexionsseismisches Programm, 1st ed. Springer, Berlin.

Molenaar, N., Felder, M., Bär, K., Götz, A.E., 2015. What classic greywacke (litharenite) can reveal about feldspar diagenesis: An example from Permian Rotliegend sandstone in Hessen, Germany. Sedimentary Geology 326, 79-93. https://doi.org/10.1016/..sedgeo.2015.07.002.

Mosegaard, K., Tarantola, A., 1995. Monte Carlo sampling of solutions to inverse problems. J. Geophys. Res. 100 (B7), 12431-12447. https://doi.org/10.1029/94JB03097.

Müller, H., 1996. Das Permokarbon im nördlichen Oberrheingraben: Paläogeographische und strukturelle Entwicklung des permokarbonen Saar-Nahe-Beckens im nördlichen Oberrheingraben. Hess. Landesamt für Bodenforschung, Wiesbaden, 85 pp.

Okrusch, M., 1995. Metamorphic Evolution, in: Dallmeyer, R.D., Franke, W., Weber, K. (Eds.), Pre-Permian Geology of Central and Eastern Europe. Springer Berlin Heidelberg, Berlin, Heidelberg, pp. 201-213.

Okrusch, M., Schubert, W., Nasir, S., 1995. IV.D Igneous Activity (Pre- to Early Variscan Magmatism), in: Dallmeyer, R.D., Franke, W., Weber, K. (Eds.), Pre-Permian Geology of Central and Eastern Europe. Springer Berlin Heidelberg, Berlin, Heidelberg, pp. 190-200.

Oncken, O., 1995. III.B.2 Structure, in: Dallmeyer, R.D., Franke, W., Weber, K. (Eds.), PrePermian Geology of Central and Eastern Europe. Springer Berlin Heidelberg, Berlin, Heidelberg, pp. 50-58.

Oncken, O., 1997. Transformation of a magmatic arc and an orogenic root during oblique collision and its consequences for the evolution of the European Variscides (Mid-German Crystalline Rise). Geologische Rundschau 86 (1), 2-20. https://doi.org/10.1007/s005310050118.

Oncken, O., 1998. Orogenic mass transfer and reflection seismic patterns - evidence from DEKORP sections across the European Variscides (central Germany). Tectonophysics 286, 47-61. https://doi.org/10.1016/S0040-1951(97)00254-0.

Oncken, O., Winterfeld, C. von, Dittmar, U., 1999. Accretion of a rifted passive margin: The Late Paleozoic Rhenohercynian fold and thrust belt (Middle European Variscides). Tectonics 18 (1), 75-91. https://doi.org/10.1029/98TC02763.

Reinhold, C., Schwarz, M., Bruss, D., Heesbeen, B., Perner, M., Suana, M., 2016. The Northern Upper Rhine Graben : re-dawn of a mature petroleum province? Swiss Bull angew. Geol. 21, 35-56. https://doi.org/10.5169/seals-658196.

Reischmann, T., Anthes, G., Jaeckel, P., Altenberger, U., 2001. Age and origin of the Böllsteiner Odenwald. Mineralogy and Petrology 72 (1-3), 29-44. https://doi.org/10.1007/s007100170025.

Rotstein, Y., Edel, J.-B., Gabriel, G., Boulanger, D., Schaming, M., Munschy, M., 2006. Insight into the structure of the Upper Rhine Graben and its basement from a new compilation of Bouguer Gravity. Tectonophysics 425, 55-70. https://doi.org/10.1016/j.tecto.2006.07.002.

Rotstein, Y., Schaming, M., 2011. The Upper Rhine Graben (URG) revisited: Miocene transtension and transpression account for the observed first-order structures. Tectonics 30, 1-14. https://doi.org/10.1029/2010TC002767.

Rousset, D., Bayer, R., Guillon, D., Edel, J.B., 1993. Structure of the southern Rhine Graben from gravity and reflection seismic data (ecors-dekorp program). Tectonophysics 221 (2), 135-153. https://doi.org/10.1016/0040-1951(93)90329-I. 
Schäfer, A., 1989. Variscan molasse in the Saar-Nahe Basin (W-Germany), Upper Carboniferous and Lower Permian. International Journal of Earth Sciences 78 (2), 499524. https://doi.org/10.1007/BF01776188.

Schäfer, A., 2011. Tectonics and sedimentation in the continental strike-slip Saar-Nahe Basin (Carboniferous-Permian, West Germany). zdgg 162 (2), 127-155. https://doi.org/10.1127/1860-1804/2011/0162-0127.

Scheck-Wenderoth, M., Krzywiec, P., Zühlke, R., Maystrenko, Y., Froitzheim, N., 2008. Permian to Cretaceous tectonics of Central Europe, in: McCann, T. (Ed.), The Geology of Central Europe: Volume 1: Precambrian and Palaeozoic. Geological Society of London, London, pp. 999-1030.

Schumacher, M.E., 2002. Upper Rhine Graben: Role of preexisting structures during rift evolution. Tectonics 21 (1), 6-1-6-17. https://doi.org/10.1029/2001TC900022.

Seckendorff, V. von, Arz, C., Lorenz, V., 2004. Magmatism of the late Variscan intermontane Saar-Nahe Basin (Germany): a review. Geological Society, London, Special Publications 223 (1), 361-391. https://doi.org/10.1144/GSL.SP.2004.223.01.16.

Sissingh, W., 1998. Comparative Tertiary stratigraphy of the Rhine Graben, Bresse Graben and Molasse Basin: correlation of Alpine foreland events. Tectonophysics 300 (1-4), 249284. https://doi.org/10.1016/S0040-1951(98)00243-1.

Sittler, C., 1969. The sedimentary trough of the Rhine graben. Tectonophysics 8, 543-560. Sittler, C., 1992. Illustration de l'histoire géologique du Fossé rhénan et de l'Alsace. Neues Jahrb. für Geol. und Paläontologie Abhandlungen 186 (3), 255-282.

Skrzypek, E., Schulmann, K., Tabaud, A.-S., Edel, J.-B., 2014. Palaeozoic evolution of the Variscan Vosges Mountains. Geological Society, London, Special Publications 405 (1), 45-75. https://doi.org/10.1144/SP405.8.

Sokol, G., Nitsch, E., Anders, B., Beccaletto, L., Capar, L., Mermy, D.C., Dezayes, C., Dresmann, H., Elsass, P., Fehn, C., Fischer, G., Franz, M., Haneke, J., Huggenberger, P., Kärcher, T., Krzyzanowski, J., Oliviero, G., Prestel, R., Rodat, C., Rupf, I., Schuff, J., Siemon, S., Storz, R., Tesch, J., Urban, S., Weidenfeller, M., Wielandt-Schuster, U., Wirsing, G., Zumsprekel, H., 2013. Geopotenziale des tieferen Untergrundes im Oberrheingraben: Fachlich-Technischer Abschlussbericht des INTERREG-Projekts GeORG. Teil 1: Ziele und Ergebnisse des Projekts (Zusammenfassung), Freiburg i.Br. I Mainz / Strasbourg / Basel.

Stein, E., 2001. The geology of the Odenwald Crystalline Complex. Mineralogy and Petrology 72 (1-3), 7-28. https://doi.org/10.1007/s007100170024.

Stellrecht, R., 1971. Geologisch-tektonische Entwicklung im Raum Albersweiler/Pfalz. jber_oberrh 53, 239-262. https://doi.org/10.1127/jmogv/53/1971/239.

Stober, I., Bucher, K., 2007. Hydraulic properties of the crystalline basement. Hydrogeol J 15, 213-224. https://doi.org/10.1007/s10040-006-0094-4.

Stollhofen, H., 1998. Facies architecture variations and seismogenic structures in the Carboniferous-Permian Saar-Nahe Basin (SW Germany): evidence for extension-related transfer fault activity. Sedimentary Geology 119 (1-2), 47-83. https://doi.org/10.1016/S0037-0738(98)00040-2.

Suess, F.E., 1926. Intrusion-und Wandertektonik im variszischen Grundgebirge. Gebr. Bornträger, Berlin, $286 \mathrm{pp}$.

Timmermann, Martin, 2008. Palaeozoic magmatism, in: McCann, T. (Ed.), The Geology of Central Europe: Volume 2: Mesozoic and Cenozoic. Geological Society of London, London. 
Ündül, Ö., 2016. Assessment of mineralogical and petrographic factors affecting petrophysical properties, strength and cracking processes of volcanic rocks. Engineering Geology 210, 10-22. https://doi.org/10.1016/j.enggeo.2016.06.001.

van Zyl, J.J., 2001. The Shuttle Radar Topography Mission (SRTM): a breakthrough in remote sensing of topography. Acta Astronautica 48 (5-12), 559-565. https://doi.org/10.1016/S0094-5765(01)00020-0.

Vilà, M., Fernández, M., Jiménez-Munt, I., 2010. Radiogenic heat production variability of some common lithological groups and its significance to lithospheric thermal modeling. Tectonophysics 490 (3-4), 152-164. https://doi.org/10.1016/j.tecto.2010.05.003.

Villemin, T., Alvarez, F., Angelier, J., 1986. The Rhinegraben: Extension, subsidence and shoulder uplift. Tectonophysics 128 (1-2), 47-59. https://doi.org/10.1016/00401951(86)90307-0.

Villemin, T., Bergerat, F., 1987. L'evolution structurale du fosse rhenan au cours du Cenozoique ; un bilan de la deformation et des effets thermiques de l'extension. Bulletin de la Société Géologique de France III, 245-255. https://doi.org/10.2113/gssgfbull.III.2.245.

Weber, K., 1995a. IV.C.3 The Saar-Nahe Basin, in: Dallmeyer, R.D., Franke, W., Weber, K. (Eds.), Pre-Permian Geology of Central and Eastern Europe. Springer Berlin Heidelberg, Berlin, Heidelberg, pp. 182-185.

Weber, K., 1995b. IV.C.4 Structural Relationship Between Saar-Nahe Basin, Odenwald, and Spessart Mts., in: Dallmeyer, R.D., Franke, W., Weber, K. (Eds.), Pre-Permian Geology of Central and Eastern Europe. Springer Berlin Heidelberg, Berlin, Heidelberg, pp. 186189.

Weinert, S., Bär, K., Sass, I., 2020a. Database of Petrophysical Properties of the MidGerman Crystalline High. in review. Earth Syst. Sci. Data Discuss. https://doi.org/10.5194/essd-2020-211.

Weinert, S., Bär, K., Sass, I., 2020b. Petrophysical Properties of the Mid-German Crystalline High: A Database for Bavarian, Hessian, Rhineland-Palatinate and Thuringian Outcrops. Technical University of Darmstadt. TUdatalib. https://doi.org/10.25534/tudatalib-278.

Weinert, S., Bär, K., Sass, I., 2021, in prep. A Geological 3D-Structural Model of the Hessian Mid-German Basement. TUdatalib.

Welsch, B., Bär, K., Rühaak, W., Sass, I., 2014. An Outcrop Analogue Study on the Suitability of Crystalline Rocks as Heat Storage Media, in: Röhling, H.G., Zulauf, G. (Eds.), GeoFrankfurt 2014 - Dynamik des Systems Erde / Earth Systems Dynamics, Abstract Volume. Schweizerbart Science Publishers, Stuttgart, p. 546.

Will, T.M., Lee, S.-H., Schmädicke, E., Frimmel, H.E., Okrusch, M., 2015. Variscan terrane boundaries in the Odenwald-Spessart basement, Mid-German Crystalline Zone: New evidence from ocean ridge, intraplate and arc-derived metabasaltic rocks. Lithos 220-223, 23-42. https://doi.org/10.1016/j.lithos.2015.01.018.

Zeh, A., Gerdes, A., 2010. Baltica- and Gondwana-derived sediments in the Mid-German Crystalline Rise (Central Europe): Implications for the closure of the Rheic ocean. Gondwana Research 17 (2-3), 254-263. https://doi.org/10.1016/j.gr.2009.08.004.

Ziegler, P.A., 1990. Geological atlas of western and central Europe 1990, $2^{\text {nd }}$ ed. Shell Internationale Petroleum Maatschappij BV, The Hague, 239 pp.

Ziegler, P.A., 1992. European Cenozoic rift system. Tectonophysics 208 (1-3), 91-111. https://doi.org/10.1016/0040-1951(92)90338-7.

Ziegler, P.A., Dèzes, P., 2005. Evolution of the lithosphere in the area of the Rhine Rift System. International Journal of Earth Sciences 94 (4), 594-614. https://doi.org/10.1007/s00531-005-0474-3. 